\title{
Genomic Alterations and Their Implications on Survival in Nonmetastatic Colorectal Cancer: Status Quo and Future Perspectives
}

\author{
Reetu Mukherji ${ }^{1}{ }^{(}$, John L. Marshall ${ }^{1, *}$ and Andreas Seeber ${ }^{2}(\mathbb{D}$ \\ 1 Ruesch Center for The Cure of Gastrointestinal Cancers, Lombardi Comprehensive Cancer Center, \\ Georgetown University Medical Center, Washington, DC 20057, USA; \\ reetu.mukherji@gunet.georgetown.edu \\ 2 Department of Hematology and Oncology, Comprehensive Cancer Center Innsbruck, Medical University of \\ Innsbruck, Innsbruck A-6020, Austria; andreas.seeber@tirol-kliniken.at \\ * Correspondence: marshalj@georgetown.edu; Tel.: +1-(202)-444-0275
}

Received: 1 July 2020; Accepted: 18 July 2020; Published: 22 July 2020

\begin{abstract}
The selection of treatment according to genomic alterations is a standard approach in metastatic colorectal cancer but is only starting to have an impact in the earlier stages of the disease. The status of genes like KRAS, BRAF, and $M M R$ has substantial survival implications, and concerted research efforts have revolutionized treatment towards precision oncology. In contrast, a genomic-based approach has not changed the adjuvant setting after curative tumor-resection in the daily routine so far. This review focuses on the current knowledge regarding prognostic and predictive genomic biomarkers in patients with locally advanced nonmetastasized colorectal cancer. Furthermore, we provide an outlook on future challenges for a personalized adjuvant treatment approach in patients with colorectal cancer.
\end{abstract}

Keywords: colorectal cancer; adjuvant; chemotherapy; microsatellite instability; genomic; prognosis

\section{Introduction}

Molecular profiling and precision medicine have become a critical new standard of care in the management of patients with metastatic colorectal cancer (CRC). As is the case in other solid tumors, several key molecular abnormalities provide both prognostic and predictive support for therapeutic interventions in the management of metastatic disease. Diagnostic biomarkers determine whether a patient has CRC, prognostic biomarkers predict the likely or expected outcomes of the disease irrespective of treatment, and predictive biomarkers provide information on specific treatment responses in the presence or absence of the specified biomarker. However, few of these biomarkers are routinely used in the management of patients with stage I-III CRC (see Table 1). Up until today, virtually all clinical trials were performed in an unenriched patient population using only pathologic stage as the determining inclusion criteria. Stratifications have not been included for significant genetic abnormalities, nor have we included the still mystical distinction of right-sided versus left-sided colon cancers in clinical trials. Therefore, we are forced to use retrospective analyses to guide today's practice. With the exception of microsatellite instability (MSI), no specific clinical trials have been performed in the adjuvant setting focusing on particular molecular abnormalities. In this review, we will discuss current knowledge of key molecular markers and the role that they play either prognostically or predictively in the management of patients with non-metastatic CRC. 


\section{MSI/MMR Status}

Mismatch repair (MMR) alterations have quickly become the most important new discovery in CRC biology and treatment. MMR is an important enzyme system responsible for maintaining genomic stability and correcting erroneous single-nucleotide mismatches during DNA replication that otherwise may result in somatic or germline mutations. Mutations in MMR genes impair the system's ability to correct these errors during replication and thereby result in accelerated accumulation of mutations, especially in microsatellites. Microsatellites-numerous repeat-short sequences of nucleotide base-pairs scattered throughout the genome are susceptible to errors in replication and heavily rely on the MMR system. Germline or somatic mutations in MMR genes result in MMR deficiency (dMMR), which can lead to microsatellite hypermutation and length alterations, resulting in MSI. A tumor with an MSI-high (MSI-H) phenotype (instability in $>30 \%$ of microsatellites examined) suggests dMMR. In contrast, an MSI-stable or -low (MSS or MSI-L) phenotype (instability in $<30 \%$ of microsatellites) indicates proficient MMR (pMMR) [1]. Lynch syndrome, an inherited syndrome caused by autosomal dominantly inherited germline mutations in one of the MMR genes ( $h M L H 1, h M S H 2, h M S H 6, h P M S 2$, EPCAM), is seen in $3 \%$ of all CRC patients, whereas sporadic MSI-H status, most commonly due to inactivation of $h M L H 1$, is seen in about $5-20 \%$ of all CRCs [2-6].

MSI-H status is more frequent in stage II than stage III CRCs (22\% vs. $12 \%)$. It confers a reduced likelihood of nodal or distant metastasis, which is likely attributable to the presence of immunogenic neoantigens from hypermutation and increased lymphocytic infiltration, contributing to improved immune-surveillance and prevention of micro-metastases [7-9]. Numerous retrospective studies and systematic reviews suggest MSI-H status is associated with a better prognosis, particularly in stage II CRC [10-13]. For instance, in the Quick and Simple and Reliable (QUASAR) study, dMMR status was associated with a reduced risk of recurrence after resection in stage II CRCs (hazard ratio (HR) 0.31) [12]. This finding is in line with data coming from a broad systematic review, in which Popat et al. showed that MSI was associated with better overall survival (OS) in locally advanced CRC (HR 0.67) [13]. Thus, MSI/dMMR status is considered an independent predictor of survival, with evidence suggesting that favorable prognostic effects are more significant in stage II compared to stage III CRCs [14-17] (see also Tables 1-3).

Large meta-analyses suggest that high-risk CRCs—based on nodal status-derive more significant benefit from adjuvant therapy than less invasive disease. Patients with stage III CRC had a 5-year disease-free survival (DFS) of $63.6 \%$ and $49.0 \%$ when treated with and without adjuvant therapy, respectively, compared to $81.4 \%$ and $79.3 \%$ in patients with stage II CRC [18]. Furthermore, although recommendations for adjuvant treatment of patients with non-subtyped stage III CRCs are established based on prior studies, the role for adjuvant therapy in patients with MSI-H stage III disease is as unclear as for stage II CRCs [19-22].

Various studies have shown that patients with MSS/MSI-L/pMMR CRCs benefit from adjuvant 5-fluorouracil (5-FU)-based treatment regimens, whereas those with MSI-H/dMMR CRCs do not $[10,23,24]$. The reason for 5-FU resistance in MSI-H/dMMR tumors remains unclear. 5-FU has multiple proposed mechanisms of action, including enzyme inhibition in the DNA replication pathway leading to dinucleotide imbalances and DNA damage. Furthermore, 5-FU is a pyrimidine analog misincorporated into DNA/RNA, resulting in impaired genomic processing [25]. Preclinical studies suggest that an intact MMR system may be required to recognize 5-FU and facilitate apoptosis and cytotoxicity, and dMMR may lead to 5-FU resistance [26-28]. For instance, Arnold et al. demonstrated that dMMR $h M L H 1$ hypermethylated human CRC cell lines that underwent $h M L H 1$ promoter demethylation with 5-Aza-2'-deoxycytidine overcame 5-FU resistance in vitro [28]. 
Table 1. Biomarker Testing Currently Recommended Based on CRC Stage.

\begin{tabular}{|c|c|c|}
\hline Stage of CRC & Biomarkers Routinely Tested & Biomarker Test Utilized \\
\hline $\mathrm{I}$ & MMR/MSI status & \multirow{4}{*}{$\begin{array}{c}\text { MSI [29,30]: PCR or validated NGS panel. } \\
\text { Loss of protein expression with IHC testing of the four MMR genes (MLH1, MSH2, MSH6, PMS2) } \\
\text { should guide further genetic testing } \\
\begin{array}{c}\text { Instability in > } 30 \% \text { of microsatellites examined with PCR indicates dMMR and instability in }<30 \% \text { of } \\
\text { microsatellites indicates proficient MMR [1]. }\end{array}\end{array}$} \\
\hline II & MMR/MSI status & \\
\hline III & MMR/MSI status & \\
\hline \multirow{6}{*}{ IV } & MMR/MSI status & \\
\hline & KRAS & \multirow{3}{*}{$\begin{array}{c}\text { KRAS, NRAS, BRAF [31-36]: No specific methodology recommended } \\
\text { (e.g., sequencing, hybridization) }\end{array}$} \\
\hline & NRAS & \\
\hline & BRAF & \\
\hline & HER2 amplifications & $\begin{array}{l}\text { HER2 amplification [37-39]: IHC, FISH, or NGS; ICH positive defined as } 3+\text { staining (intense } \\
\text { membrane staining that can be circumferential, basolateral, or lateral) in more than } 50 \% \text { of tumor cells). } \\
\text { Score of } 2+\text { should be reflexed to FISH; FISH positive if HER2:CEP17 ratio } \geq 2 \text { in more than } 50 \% \text { of cells }\end{array}$ \\
\hline & NTRK fusion & NTRK fusion [40-44]: IHC, FISH, DNA-based NGS, RNA-based NGS \\
\hline
\end{tabular}

Glossary: PCR; polymerase chain reaction, MMR; mismatch repair, MSI; microsatellite instability, NGS; next-generation sequencing, IHC; immunohistochemistry, KRAS; Kirsten rat sarcoma viral oncogene homolog, HER2; human epidermal growth factor receptor 2, FISH; fluorescence in situ hybridization

Table 2. Prognostic and Predictive Molecular Biomarkers Analyzed in Nonmetastatic Colorectal Cance.

\begin{tabular}{ccc}
\hline Biomarker & Prognostic Value & Predictive Value \\
\hline KRAS & $\begin{array}{c}\text { Poor outcome in terms of DFS and OS [45-49]; In pMMR and } \\
\text { KRAS-mutated subgroup DFS shorter [50] }\end{array}$ & No predictive value for patients treated with adjuvant 5-FU [7,51] \\
\hline BRAF & Poor outcome in terms of OS in pMMR tumors [7,52-60] & No predictive value \\
\hline TP53 & Poor outcome with shorter OS, DFS and RFS [61-65] & Positive predictive biomarker for N1 tumors receiving adjuvant 5-FU [65] \\
\hline PIK3CA & Poor prognostic marker only with co-mutations in TP53 [66] & No predictive value \\
\hline MSI-H/dMMR & Associated with a better outcome [8,10-13,30], especially in stage II & Conflicting results: \\
& CRC [14-17] & Shorter survival in patients treated with adjuvant 5-FU [10,23,24,67] \\
APC & Stage II CRC had improved RFS treated with 5-FU + irinotecan [14] & Conflicting results: \\
& Poor prognostic marker in 5-FU treated stage III CRC [68] & No predictive value \\
\hline Glossary: DFS; disease-free survival, OS; overall survival, RFS; recurrence-free survival, pMMR; proficient mismatch repair, 5-FU; 5-fluorouracil, CRC; colorectal cancer \\
\hline
\end{tabular}


Table 3. Prognostic and Predictive Data Based on MSI Status in Stage II and III CRCs.

\begin{tabular}{|c|c|c|c|c|}
\hline \multirow[t]{2}{*}{ Reference Study Type Population $(n)$} & \multicolumn{2}{|c|}{ Prognostic Data and Implications } & \multicolumn{2}{|c|}{ Predictive Data and Implications } \\
\hline & Stage II & Stage III & Stage II & Stage III \\
\hline $\begin{array}{c}{[10]} \\
\text { Retrospective } \\
\text { Total, } n=953 \\
\text { MSI-H, } n=208 \\
\text { MSS, } n=745\end{array}$ & $\begin{array}{c}\text { MSI-H }(n=120) \text { vs. MSS }(n= \\
\text { 371) } 5 \text {-FU treated and no ACT; } \\
\text { Cumulative survival } \\
\text { Log rank } 10.5, p=0.001 \\
\text { yes survival benefit with MSI-H }\end{array}$ & $\begin{array}{c}\text { MSI-H }(n=88) \text { vs. MSS }(n=374) \\
5 \text {-FU treated and no ACT } \\
\text { Cumulative survival } \\
\text { Log rank } 7.25, p=0.007 \\
\text { yes survival benefit with MSI-H }\end{array}$ & $\begin{array}{c}\text { 5-FU treated vs. no ACT } \\
\text { MSI-H } \\
\text {-year survival } \\
\text { Log rank } 2.0, p=0.151 \\
\text { no survival benefit, trend for worse outcome } \\
\text { with 5-FU } \\
\text { MSS } \\
5 \text {-year survival } \\
\text { Log rank } 0.97, p=0.323 \\
\text { no survival benefit with 5-FU }\end{array}$ & $\begin{array}{c}\text { 5-FU treated vs. no ACT } \\
\text { MSI-H } \\
\text { 5-year survival } \\
\text { Not reported, but per discussion no statistically } \\
\text { significant difference } \\
\text { no significant survival benefit with 5-FU } \\
\text { MSS } \\
5 \text {-year survival } \\
\text { Log rank } 5.39, p=0.02 \\
\text { yes survival benefit with 5-FU }\end{array}$ \\
\hline $\begin{aligned} \text { [23] Retrospective Total, } & \\
n & =570 \\
\text { MSI-H, } n & =95 \mathrm{MSS} / \mathrm{MSI}-\mathrm{L}, \\
n & =475\end{aligned}$ & $\begin{array}{c}\text { MSI- } H \text { vs. MSS } \\
\text { 5-FU treated and no ACT } \\
\text { HR for OS 0.61 (95\% CI 0.38-0.96) for } \\
\text { combined stage II and III CRC (no } \\
\text { by-stage analysis reported) } \\
\text { No ACT } \\
\text { HR for OS 0.32 (95\% CI } 0.14-0.75) \text { for } \\
\text { combined stage II and III CRC (no } \\
\text { by-stage analysis reported) }\end{array}$ & $\begin{array}{c}\text { MSI-H vs. MSS } \\
\text { 5-FU treated and no ACT } \\
\text { HR for OS 0.61 (95\% CI 0.38-0.96) for } \\
\text { combined stage II and III CRC (no by-stage } \\
\text { analysis reported) } \\
\text { No ACT } \\
\text { HR for OS 0.32 (95\% CI } 0.14-0.75 \text { ) for } \\
\text { combined stage II and III CRC (no by-stage } \\
\text { analysis reported) }\end{array}$ & $\begin{array}{c}\text { 5-FU treated vs. no ACT } \\
\text { MSI-H } \\
\text { HR for death } 3.28 \text { (95\% } \mathrm{CI} 0.86-12.48) \\
\text { no survival benefit, but trend for worse } \\
\text { outcome with 5-FU } \\
\text { MSS/MSI-L } \\
\text { HR for death } 0.67 \text { (95\% CI } 0.39-1.15) \\
\text { no survival benefit, but trend for improved } \\
\text { outcome with 5-FU }\end{array}$ & $\begin{array}{c}\text { 5-FU treated vs. no ACT } \\
\text { MSI-H } \\
\text { HR for death } 1.42 \text { ( } 95 \% \text { CI } 0.36-5.56) \\
\text { no survival benefit, but trend for worse } \\
\text { outcome with 5-FU } \\
\text { MSS/MSI-L } \\
\text { HR for death } 0.69 \text { ( } 95 \% \text { CI } 0.47-1.01) \\
\text { no survival benefit, but trend for improved } \\
\text { outcome with 5-FU }\end{array}$ \\
\hline $\begin{array}{c}\text { [24] } \\
\text { Prospective analysis of data on patients } \\
\text { previously enrolled in } 5 \text { completed } \\
\text { randomized clinical trials } \\
\text { Total, } n=457 \\
\text { dMMR, } n=70 \\
\text { pMMR, } n=387 \\
\text { Analysis of data pooled with prior data from } \\
\text { four of the five clinical trials [23] }\end{array}$ & $\begin{array}{c}\text { MSI- } H \text { vs. MSS } \\
\text { No by-stage analysis reported }\end{array}$ & $\begin{array}{c}\text { MSI- } H \text { vs. MSS } \\
\text { No by-stage analysis reported }\end{array}$ & $\begin{array}{c}\text { 5-FU treated vs. no ACT } \\
\text { Prospective analysis data } \\
\underline{\text { dMMR }} \\
\text { inadequate sample size prohibited analysis } \\
\text { pMMR } \\
\begin{array}{c}\text { HR for 5-year DFS 1.01 (95\% CI } 0.56-1.83) \\
\text { no survival benefit with 5-FU }\end{array}\end{array}$ & $\begin{array}{c}\text { 5-FU treated vs. no ACT } \\
\text { Prospective analysis data } \\
\text { dMMR } \\
\text { inadequate sample size prohibited analysis } \\
\text { pMMR } \\
\text { HR for 5-year DFS 0.56 (95\% CI 0.37-0.83) } \\
\text { HR for OS consistent with DFS } \\
\text { yes survival benefit with 5-FU }\end{array}$ \\
\hline $\begin{array}{c}\text { Pooled data: } \\
\text { Total, } n=1027 \\
\text { dMMR, } n=165 \\
\text { pMMR, } n=862\end{array}$ & & & 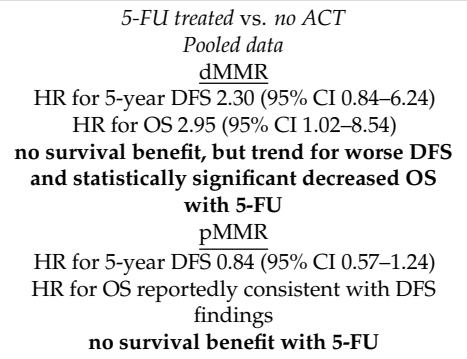 & 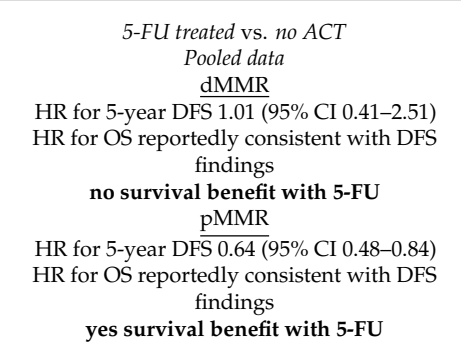 \\
\hline
\end{tabular}


Table 3. Cont

\begin{tabular}{|c|c|c|c|c|}
\hline \multirow[t]{2}{*}{ Reference Study Type Population $(n)$} & \multicolumn{2}{|c|}{ Prognostic Data and Implications } & \multicolumn{2}{|c|}{ Predictive Data and Implications } \\
\hline & Stage II & Stage III & Stage II & Stage III \\
\hline $\begin{array}{c}{[67]} \\
\text { Prospective } \\
\text { Total, } n=505 \\
\text { dMMR, } n=53 \\
\text { pMMR, } n=452 \\
\text { (9 out of } 505 \text { patients excluded from benefit of } \\
\text { ACT analysis as they did not get } 5-\mathrm{FU})\end{array}$ & $\begin{array}{c}d M M R(n=35) \text { vs. } p M M R(n=261) \\
5 \text {-FU treated and no ACT } \\
80 \% \text { vs. } 75 \% \text { DFS respectively, } p=0.5 \\
89 \% \text { vs. } 85 \% \text { OS respectively, } p=0.6 \\
\text { no survival benefit, according to MMR } \\
\text { status }\end{array}$ & $\begin{array}{c}d M M R(n=18) \text { vs. } p M M R(n=191) \\
5 \text {-FU treated and no ACT } \\
73 \% \text { vs. } 61 \% \text { DFS respectively, } p=0.4 \\
78 \% \text { vs. } 75 \% \text { OS respectively, } p=0.8 \\
\text { no survival benefit according to MMR status }\end{array}$ & $\begin{array}{c}\text { 5-FU treated vs. no ACT } \\
\text { dMMR } \\
\text { no improvement in probability of survival } \\
(89.5 \% \text { vs. } 82.4 \%, p=0.4) \text { and DFS (73.7\% vs. } \\
79.4 \%, p=0.9) \text { with adjuvant therapy in stage } \\
\text { II/III CRC } \\
\text { Trend reportedly maintained in subgroup } \\
\text { analysis stage II disease } \\
\text { no survival benefit with 5-FU }\end{array}$ & $\begin{array}{c}\text { 5-FU treated vs. no ACT } \\
\text { dMMR } \\
\text { no improvement in probability of survival } \\
(89.5 \% \text { vs. } 82.4 \%, p=0.4) \text { and DFS (73.7\% vs. } \\
79.4 \%, p=0.9) \text { with adjuvant therapy in stage } \\
\text { II/III CRC } \\
\text { Trend reportedly maintained in subgroup } \\
\text { analysis stage III disease } \\
\text { no survival benefit with } 5 \text {-FU }\end{array}$ \\
\hline & & & $\begin{array}{c}\text { pMMR } \\
\text { improved probability of overall survival ( } 87.1 \% \\
\text { vs. } 73.5 \%, p=0.0001) \text { and DFS }(73.9 \% \text { s. } \\
64.0 \% p=0.0004) \text { with adjuvant therapy in } \\
\text { stage II/III CRCs } \\
\text { Trend reportedly maintained in subgroup } \\
\text { analysis stage II disease } \\
\text { yes survival benefit with } 5 \text {-FU }\end{array}$ & $\begin{array}{c}\text { pMMR } \\
\text { improved probability of overall survival (87.1\% } \\
\text { vs. 73.5\%, } p=0.0001 \text { ) and DFS (73.9\% vs. } \\
64.0 \% p=0.0004 \text { ) with adjuvant therapy in } \\
\text { stage II/III CRCs } \\
\text { Trend reportedly maintained in subgroup } \\
\text { analysis stage III disease } \\
\text { yes survival benefit with 5-FU }\end{array}$ \\
\hline $\begin{array}{c}\text { [73] } \\
\text { Retrospective based QUSAR } \\
\text { subgroup analysis } \\
\text { Total, } n=1913 \\
\text { dMMR, } n=218 \\
\text { pMMR, } n=1695\end{array}$ & $\begin{array}{c}d M M R(n=167) \text { vs. } p M M R(n=469) \text { in } \\
\text { right-sided } C R C \\
5 \text {-FU treated and no ACT } \\
\text { Risk of recurrence ratio } 0.44(95 \% \text { CI } \\
0.29-0.67) \\
\text { yes survival benefit with dMMR } \\
\text { 5-FU } \\
\text { OR for recurrence } 0.36(95 \% \text { CI } 0.20-0.65) \\
\text { yes survival benefit if dMMR }\end{array}$ & not reported & $\begin{array}{c}5-F U(n=311) \text { vs. no } A C T(n=325) \\
\text { dMMR }(n=167) \\
2 \text { year OR for recurrence } 0.45(95 \% \text { CI } 0.09-2.23) \\
\text { no survival benefit, but trend for improved } \\
\text { outcome with 5-FU } \\
\text { pMMR }(n=469) \\
2 \text { year OR for recurrence } 1.07(95 \% \text { CI } 0.61-1.87) \\
\text { no survival benefit with 5-FU }\end{array}$ & Not reported \\
\hline & $\begin{array}{l}\text { No ACT } \\
\text { OR for recurrence 0.54 ( } 95 \% \text { CI } 0.30-0.97) \\
\text { yes survival benefit if dMMR }\end{array}$ & & & \\
\hline $\begin{array}{c}{[74]} \\
\text { Retrospective cohort study for stage II CRC } \\
\text { MSI, } n=843 \\
\text { MSS, } n=6121\end{array}$ & 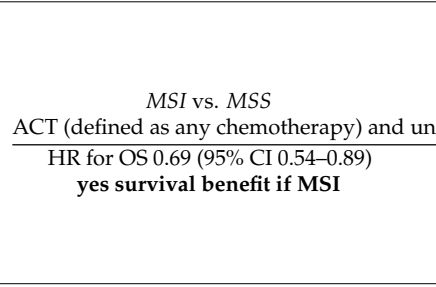 & ntreated & $\begin{array}{c}\text { ACT (defined as any chemotherapy) vs. no ACT } \\
\text { MSI }(n=843) \\
\text { HR } 0.85(95 \% \text { CI } 0.39-1.83) \\
\text { no survival benefit with ACT } \\
\text { MSS }(n=6162) \\
\text { HR } 0.47(95 \% 0.37-0.60) \\
\text { yes survival benefit with ACT } \\
\text { MSS subset with no high-risk features }(n=3400) \\
\text { HR } 0.44(95 \% \text { CI } 0.28-0.71) \\
\text { yes survival benefit with ACT }\end{array}$ & No stage III data \\
\hline $\begin{array}{c}{[75]} \\
\text { Retrospective } \\
\text { Stage III only all treated with FOLFOX } \\
\text { Total, } n=598 \\
\text { MSI-H, } n=50 \\
\text { MSS/MSI-L, } n=548\end{array}$ & Not analyzed & $\begin{array}{c}\text { MSI-H }(n=50) \text { vs. MSS/MSI-L }(n=548) \text { treated } \\
\text { with FOLFOX } \\
\text { HR for DFS } 0.598(95 \% \text { CI } 0.263-1.58) \\
\text { HR for OS } 0.872(95 \% \text { CI } 0.352-2.163)\end{array}$ & Not analyzed & Not analyzed \\
\hline
\end{tabular}


Table 3. Cont

\begin{tabular}{|c|c|c|c|c|}
\hline \multirow[t]{2}{*}{ Reference Study Type Population $(n)$} & \multicolumn{2}{|c|}{ Prognostic Data and Implications } & \multicolumn{2}{|c|}{ Predictive Data and Implications } \\
\hline & Stage II & Stage III & Stage II & Stage III \\
\hline \multicolumn{5}{|c|}{$\begin{array}{l}\text { no survival benefit, with trend for improved } \\
\text { outcomes if MSI-H }\end{array}$} \\
\hline $\begin{array}{c}{[76]} \\
\text { Retrospective } \\
\text { Subgroup analysis } \\
\text { Stage II and III } \\
\text { ACT in this study was 5-FU or capecitabine } \\
\text { monotherapy } \pm \text { oxaliplatin } \\
\text { Total, } n=654 \\
\text { MSI, } n=63 \\
\text { MSS, } n=591\end{array}$ & Not analyzed & $\begin{array}{c}\text { MSI vs. MSS } \\
\text { ACT }(n=203) \\
\text { HR for RFS (recurrence) } 2.60(95 \% \text { CI 1.27-5.35) } \\
\text { HR for disease-specific survival DSS 2.35 (95\% } \\
\text { CI 0.68-8.09) } \\
\text { no survival benefit and worse RFS in ACT } \\
\text { treated if MSI-H } \\
\text { No treatment }(n=96) \\
\text { HR for RFS } 3.21(95 \% \text { CI } 0.68-15.04) \\
\text { HR for DSS } 0.75(95 \% \text { CI } 0.09-5.77) \\
\text { no survival benefit if no ACT and MSI-H }\end{array}$ & Not analyzed & $\begin{array}{c}\text { ACT vs. no ACT } \\
\text { MSI } \\
\begin{array}{c}\text { HR for survival benefit } 0.67 \text { ( } 95 \% \text { CI } 0.08-8.15) \\
\text { no survival benefit, but trend for improved } \\
\text { outcome with ACT } \\
\text { MSS }\end{array} \\
\text { HR for survival benefit } 0.35 \text { ( } 95 \% \text { CI } 0.17-0.69) \\
\text { yes survival benefit with ACT }\end{array}$ \\
\hline $\begin{array}{c}\text { [77] } \\
\text { Retrospective } \\
\text { data from patients with 5-FU based ACT } \\
\text { previously enrolled in } 2 \text { randomized trials } \\
\text { (ECOG E2284 and E2288-adjuvant stage II/III } \\
\text { studies with combinations of 5-FU with } \\
\text { leucovorin or levamisole) } \\
\text { Total (Stage III), } n=229 \\
\text { MSI-H (stage III), } n=73 \\
\text { MSI-L (stage III), } n=156\end{array}$ & Not reported & $\begin{array}{c}\text { MSI }(n=73) \text { vs. MSS }(n=156) \text { (having received } \\
5 \text {-FU based chemotherapy) } \\
64 \% \text { and } 49 \% \text {-year DFS respectively }(p=0.02) \\
68 \% \text { and } 56 \% 5 \text {-year OS respectively }(p=0.20) \\
\text { yes DFS benefit, with trend for improved OS } \\
\text { if MSI }\end{array}$ & $\begin{array}{l}\text { Study reports no predictive value seen, } \\
\text { possibly due to small sample size }(n=121) \\
\text { no survival benefit between different 5-FU } \\
\text { based regimens }\end{array}$ & $\begin{array}{c}\text { Study reports no relationship between survival } \\
\text { after treatment with a particular regimen and } \\
\text { presence of molecular markers (no data } \\
\text { reported) } \\
\text { no survival benefit between different 5-FU } \\
\text { based regimens }\end{array}$ \\
\hline \multirow[t]{2}{*}{$\begin{array}{c}{[14]} \\
\text { Retrospective subgroup analysis from } \\
\text { PETACC 3-EORTC 40993-SAKK 60/00 trial } \\
\text { Total, } n=1254 \\
\text { MSI-H, } n=190 \\
\text { MSS/MSI-L, } n=1064\end{array}$} & $\begin{array}{c}\text { MSI- } H \text { vs. MSS/MSI- } L \\
\text { 5-FU } \pm \text { irinotecan } \\
\text { HR for RFS } 0.26(95 \% \text { CI } 0.11-0.65) \\
\text { HR for OS } 0.153(95 \% \text { CI } 0.037-0.631) \\
\text { yes survival benefit with MSI-H } \\
\text { 5-FU } \\
\text { HR for RFS } 0.22(95 \% \text { CI } 0.05-0.94) \\
\text { HR OS } 0.17(95 \% \text { C } 0.02-1.26) \\
\text { yes RFS survival benefit with 5-FU if } \\
\text { MSI-H }\end{array}$ & $\begin{array}{c}\text { MSI- } H \text { vs. MSS/MSI- } L \\
\text { 5-FU } \pm \text { irinotecan } \\
\text { HR for RFS } 0.69(95 \% \text { CI } 0.47-1.01) \\
\text { HR for OS } 0.674 \text { ( } 95 \% \text { CI } 0.426-1.07) \\
\text { no survival benefit with MSI-H, but trend } \\
\text { for improved survival with MSI-H } \\
\text { 5-FU } \\
\text { HR for RFS } 0.59 \text { (95\% CI } 0.34-1.02) \\
\text { HR for OS } 0.54(95 \% \text { CI } 0.28-1.07)\end{array}$ & $\begin{array}{c}\text { 5-FU/Irinotecan vs. 5-FU } \\
\text { MSII-H } \\
\text { HR for RFS } 1.68 \text { ( } 95 \% \text { CI } 0.28-10.05) \\
\text { HR for OS } 1.14(95 \% \text { CI } 0.07-18.2) \\
\text { no survival benefit with addition of } \\
\text { irinotecan to } 5 \text {-FU } \\
\text { MSS/MSI-LHR for RFS } 1.25(95 \% \text { CI } 0.76-2.06) \\
\text { HR for OS } 1.30 \text { ( } 95 \% \text { CI } 0.71-2.39) \\
\text { no survival benefit with addition of } \\
\text { irinotecan to 5-FU }\end{array}$ & 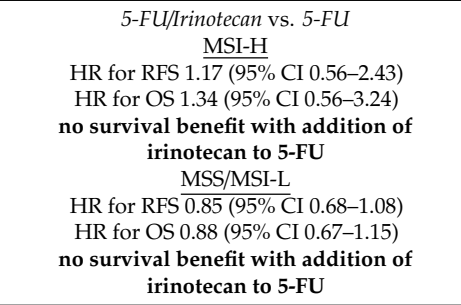 \\
\hline & $\begin{array}{c}\text { 5-FU/Irinotecan } \\
\text { HR for RFS 0.29 (95\% CI } 0.09-0.96) \\
\text { HR OS 0.14 (95\% CI 0.02-1.03) } \\
\text { yes RFS survival benefit with } \\
\text { 5-FU/irinotecan if MSI-H }\end{array}$ & $\begin{array}{c}\text {-no survival benefit but trend for improved } \\
\text { RFS and OS with 5-FU if MSI-H } \\
\text { 5-FU/Irinotecan } \\
\text { HR for RFS } 0.82(95 \% \text { CI } 0.48-1.40) \\
\text { HR for OS } 0.85 \text { ( } 95 \% \text { CI } 0.45-1.58) \\
\text { no survival benefit with 5-FU/irinotecan if } \\
\text { MSI-H }\end{array}$ & & \\
\hline
\end{tabular}


Table 3. Cont

\begin{tabular}{|c|c|c|c|c|}
\hline \multirow[t]{2}{*}{ Reference Study Type Population $(n)$} & \multicolumn{2}{|c|}{ Prognostic Data and Implications } & \multicolumn{2}{|c|}{ Predictive Data and Implications } \\
\hline & Stage II & $\begin{array}{l}\text { Stage III } \\
\end{array}$ & Stage II & Stage III \\
\hline $\begin{array}{c}{[15]} \\
\text { Retrospective } \\
\text { Results of PETACC-3 } \\
\text { Total, } n=1254 \\
\text { MSI-H, } n=190 \\
\text { MSS/MSI-L, } n=1064\end{array}$ & $\begin{array}{c}\text { MSI-H vs. MSS/MSI-L } \\
\text { 5-FU } \pm \text { irinotecan } \\
\text { HR for RFS 0.26 (95\% CI } 0.10-0.65) \\
\text { HR for OS 0.16 (95\% CI 0.04-0.64) } \\
\text { yes survival benefit if MSI-H } \\
\frac{5-\text {-FU }}{\text { HR for RFS } 0.22(95 \% \text { CI } 0.05-0.91)} \\
\text { HR for OS } 0.18(95 \% 0.02-1.32)\end{array}$ & $\begin{array}{c}\text { MSI- } H \text { vs. MSS/MSI- } L \\
\text { 5-FU } \pm \text { irinotecan } \\
\text { HR for RFS } 0.67(95 \% \text { CI } 0.46-0.99) \\
\text { HR for OS } 0.70 \text { ( } 95 \% \text { CI } 0.44-1.09) \\
\text { yes RFS survival benefit, with trend for OS } \\
\text { benefit if MSI-H. } \\
\text { - } \\
\text { HR for RFS } 0.56 \text { ( } 95 \% \text { CI } 0.32-0.96) \\
\text { HR for OS } 0.51(0.26-1.00)\end{array}$ & $\begin{array}{c}\text { 5-FU vs. F-FU//rinotecan } \\
\text { Study reports similar RFS and OS when } \\
\text { stratified by MSI status; by stage analysis not } \\
\text { reported }\end{array}$ & $\begin{array}{c}5-F U \text { vs. F-FU//rinotecan } \\
\text { Study reports similar RFS and OS when } \\
\text { stratified by MSI status; by stage analysis not } \\
\text { reported }\end{array}$ \\
\hline & $\begin{array}{c}\text { yes RFS survival benefit, with trend for } \\
\text { OS benefit if MSI-H } \\
\text { 5-FU/Irinotecan } \\
\text { HR for RFS } 0.30(95 \% \text { CI } 0.09-0.96) \\
\text { HR for OS } 0.14 \text { (95\% CI } 0.02-0.03) \\
\text { yes RFS survival benefit, with trend for } \\
\text { OS benefit if MSI-H } \\
\text { prognosis for MSI remains regardless } \\
\text { of treatment with 5-FU or } \\
\text { F-FU/irinotecan }\end{array}$ & $\begin{array}{c}\text { yes RFS survival benefit, with trend for OS } \\
\text { benefit if MSI-H } \\
5 \text {-FU/Irinotecan } \\
\text { HR for RFS } 0.82(95 \% \text { CI } 0.48-1.40) \\
\text { HR for OS } 0.94 \text { (95\% CI } 0.52-1.72) \\
\text { no survival benefit, with slight trend for } \\
\text { improved RFS if MSI-H } \\
\text { not as significant of a survival benefit } \\
\text { compared to MSI-H status in stage II }\end{array}$ & & \\
\hline $\begin{array}{c}{[7]} \\
\text { Retrospective } \\
\text { Subgroup analysis } \\
\text { PETACC-3 } \\
\text { Total, } n=1254 \\
\text { MSI-H, } n=190 \\
\text { MSS/MSI-L, } n=1064\end{array}$ & $\begin{array}{l}\text { MSI-H }(n=86) \text { vs. MSS/MSI-L }(n=309) \\
\text { HR for RFS } 0.27(95 \% \text { CI } 0.10-0.72) \\
\text { HR for OS } 0.14(95 \% \text { CI } 0.03-0.64) \\
\text { yes survival benefit if MSI-H }\end{array}$ & $\begin{array}{c}\text { MSI- } H(n=104) \text { vs. MSS } / \text { MSI- } L(n=755) \\
\text { HR for RFS } 0.59(95 \% \text { CI } 0.38-0.91) \\
\text { HR for OS 0.48 }(95 \% \text { CI } 0.28-0.81) \\
\text { yes survival benefit if MSI-H }\end{array}$ & $\begin{array}{c}\text { 5-FU vs. 5-FU//irinotecan } \\
\text { MSI-H } \\
\text { Stratified data not included } \\
\text { MSS/MSI-L } \\
\text { HR for RFS } \\
0.79(95 \% \text { CI } 0.47-1.31) \\
\text { HR for OS } 0.75 \text { ( } 95 \% \text { CI } 0.40-1.40) \\
\text { no survival benefit with addition of } \\
\text { irinotecan to } 5 \text {-FU }\end{array}$ & 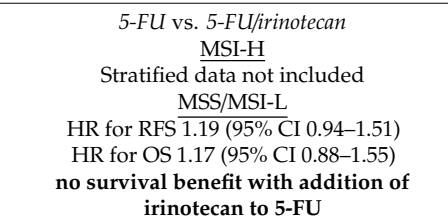 \\
\hline $\begin{array}{c}{[78]} \\
\text { Prospective updated analysis on CALGB } 9581 \\
\text { and CALGB 89803 } \\
\text { Total, } n=3002 \\
\text { dMMR, } n=330 \\
\text { pMMRR } n=1515 \\
\text { CALGB } 9581 \text { (stage II) } \\
\text { Total, } n=935 \\
\text { dMMR, } n=199 \\
\text { pMMR, } n=736 \\
\text { CALGB } 89803 \text { (stage III) } \\
\text { Total, } n=910 \\
\text { dMMR, } n=131 \\
\text { pMMR, } n=779\end{array}$ & $\begin{array}{c}d M M R(n=199) \text { vs. } p M M R(n=736) \\
\text { HR for 5y DFS } 0.65(95 \% \text { CI } 0.47-0.89) \\
\text { HR for 5y OS } 0.76(95 \% \text { CI } 0.54-1.07) \\
\text { yes DFS benefit with dMMR with trend } \\
\text { for improved OS }\end{array}$ & $\begin{array}{c}d M M R(n=131) \text { vs. } p M M R(n=779) \\
\text { HR for } 5 y \text { DFS } 0.82(95 \% \text { CI } 0.60-1.11) \\
\text { HR for 5y OS } 0.88(95 \% \text { CI } 0.63-1.22) \\
\text { no survival benefit with dMMR }\end{array}$ & $\begin{array}{c}\text { No ACT vs. MoAb 17-1A (clinical trial } \\
\text { monoclonal antibody) } \\
\text { dMMR }(n=199) \\
\text { HR for 5y DFS } 1.21(95 \% \text { CI } 0.68-2.18) \\
\text { HR for 5y OS } 1.22(95 \% \text { CI } 0.66-2.26) \\
\text { no survival benefit in untreated } \\
\text { pMMR }(n=736) \\
\text { HR for } 5 \text { DFS } 0.96(95 \% \text { CI } 0.74-1.24) \\
\text { HR for } 5 \text { y OS } 1.03(95 \% \text { CI } 0.78-1.37) \\
\text { no survival benefit in untreated }\end{array}$ & $\begin{array}{c}\text { 5-FU/LV vs. IFL } \\
\text { dMMR }(n=131) \\
\text { HR for 5y DFS 0.68 (95\% CI 0.38-1.20) } \\
\text { HR for 5y OS 0.85 (95\% CI 0.46-1.59) } \\
\text { no survival benefit, but slight trend in } \\
\text { improved outcome with addition of } \\
\text { irinotecan } \\
\text { pMMR }(n=779) \\
\text { HR for 5y DFS } 1.09(95 \% \text { CI } 0.88-1.34) \\
\text { HR for 5y OS } 1.03(95 \% \text { CI } 0.82-1.31) \\
\text { no survival benefit with addition of } \\
\text { irinotecan }\end{array}$ \\
\hline
\end{tabular}


Table 3. Cont

\begin{tabular}{|c|c|c|c|c|}
\hline \multirow[t]{2}{*}{ Reference Study Type Population $(n)$} & \multicolumn{2}{|c|}{ Prognostic Data and Implications } & \multicolumn{2}{|c|}{ Predictive Data and Implications } \\
\hline & Stage II & Stage III & Stage II & Stage III \\
\hline $\begin{array}{c}{[79]} \\
\text { Retrospective } \\
\text { Subgroup analysis } \\
\text { Stage II dMMR, } n=149 \\
\text { Stage III dMMR, } n=187\end{array}$ & Not analyzed & Not analyzed & $\begin{array}{c}\text { 5-FP or 5-FP o oxaliplatin vs. no ACT } \\
\text { dMMR }(n=149) \\
\text { HR for DFS } 0.85(95 \% \text { CI } 0.19-3.88) \text { with 5-FP } \\
\text { HR for DFS } 0.13(95 \% \text { CI } 0.02-1.05) \text { with 5-FP+ } \\
\text { oxaliplatin } \\
\text { no survival benefit with 5-FP or } \\
\begin{array}{c}\text {-FP+oxaliplatin, with trend for improved } \\
\text { survival with oxaliplatin added to 5-FP }\end{array}\end{array}$ & $\begin{array}{c}\text { 5-FP or 5-FP + oxaliplatin vs. no ACT } \\
\text { dMMR }(n=187) \\
\text { HR for DFS } 0.66(95 \% \text { CI } 0.29-1.50) \text { with } 5 \text {-FP } \\
\text { HR for DFS } 0.41 \text { (95\% CI } 0.19-0.87) \text { with 5-FP + } \\
\text { oxaliplatin } \\
\text { yes survival benefit with 5-FP in } \\
\text { combination with oxaliplatin but not 5-FP } \\
\text { alone }\end{array}$ \\
\hline $\begin{array}{c}\text { [80] } \\
\text { Retrospective } \\
\text { Subgroup analysis } \\
\text { Stage III CRC only } \\
\text { Total, } n=233 \\
\text { MSI, } n=32 \\
\text { MSS, } n=201\end{array}$ & Not included & $\begin{array}{l}\text { MSI vs. MSS (5-FU } \pm \text { oxaliplatin) } \\
\text { HR for DFS } 1.09 \text { ( } 95 \% \text { CI } 0.48-2.13) \\
\text { no survival benefit if MSI-H }\end{array}$ & Not included & $\begin{array}{c}\text { FOLFOX ( } n=109) \text { vs. 5-FU/LV }(n=124) \\
\text { MSI } \\
\text { HR for DFS } 0.17(95 \% \text { CI } 0.04-0.68) \\
\text { yes survival benefit if oxaliplatin is added } \\
\text { MSS } \\
\text { HR for DFS } 0.66 \text { (95\% CI } 0.38-1.15) \\
\text { no survival benefit, but trend for improved } \\
\text { DFS if oxaliplatin added }\end{array}$ \\
\hline
\end{tabular}


Results from a retrospective study carried out by Ribic et al. indicated that adjuvant therapy improved outcomes in patients with stage II and III MSI-L/MSS CRCs but worsened outcomes in patients with stage II and III MSI-H CRCs [23]. Another study showed a survival advantage in patients with stage III MSI-L/MSS CRCs but not in those with stage II MSI-L/MSS CRCs or stage II/III MSI-H/dMMR CRCs [10]. In a later study, investigators reported improved DFS with 5-FU-based adjuvant therapy in pMMR stage II and III CRC patients but not in those with dMMR [24]. In fact, consistent with the findings by Ribic et al., adjuvant therapy was associated with reduced OS in patients with stage II dMMR CRC compared to surgery alone (HR 2.95). On the other hand, investigators of the QUASAR trial found no association between MMR status within stage II CRC and patient benefit derived from adjuvant chemotherapy [12]. The lack of benefit in using adjuvant 5-FU-based therapy in tumors with MSI is also seen in a large systemic review [13]. One prospective study led to findings consistent with those in the aforementioned retrospective studies with better outcomes from adjuvant fluorouracil-based chemotherapy only with pMMR stage II and III CRCs and no benefit in dMMR CRCs [67]. A retrospective subgroup analysis of the PETACC-3 trial led to the discovery that adjuvant chemotherapy (5-FU \pm irinotecan) of patients with stage II MSI-H/dMMR CRCs led to improved recurrence-free survival (RFS) but not OS [14]. No improvement in either RFS or OS was apparent in patients with stage III CRCs.

Nonetheless, the majority of studies suggest that, although MSI-H/dMMR status is associated with favorable patient prognosis, it is not predictive for response to adjuvant therapy, with some data suggesting detrimental outcomes with adjuvant treatment, especially in stage II disease $[23,24,73,74,78]$. Thus, the current National Comprehensive Cancer Network (NCCN) and European Society of Medical Oncology (ESMO) guidelines recommend against routine adjuvant therapy for MSI-H stage II CRC. In patients with stage II MSS/pMMR CRCs, the decision for adjuvant treatment (5-FU/leucovorin or capecitabine) should be based on the presence of other clinical high-risk factors for recurrence (e.g., localized perforation, bowel obstruction, neuronal/vascular invasion, lymph node status, and margin status), anticipated morbidity of treatment, and patient preference $[22,81]$. The current NCCN and ESMO guidelines recommend that patients with stage III CRCs should receive adjuvant therapy, irrespective of MSI/MMR status [18,82].

Recent studies suggest that MSI/MMR status and other molecular markers may affect responses to different adjuvant chemotherapies and influence outcomes amongst those high-risk stage II and III CRCs (see Table 3). As previously discussed, preclinical models suggest MSI may be a negative predictive marker for response to 5-FU [28,83,84], and human clinical studies suggested a lack of benefit with 5-FU therapy in dMMR stage II and III CRCs compared to pMMR [24,67]. However, some preclinical models suggest MSI may confer higher sensitivity to irinotecan, a camptothecin derivative that inhibits DNA topoisomerase I and causes double-strand DNA breaks, inhibition of DNA synthesis, and arrest of the cell cycle in the synthesis and gap 2 phases of interphase [85-87]. For example, Vilar et al. demonstrated that human CRC cell lines that were MSI-H due to $h M L H 1$ inactivation were four to nine times more sensitive to topoisomerase I inhibition compared to MSS cell lines [87]. dMMR CRCs tend to accumulate mutations in genes involved in double-strand DNA break repair, and it is suggested that they are chemosensitized by agents such as irinotecan due to their faulty repair system $[87,88]$. In the prospective CALGB 89803 study, high-risk patients with stage II and III CRCs were randomized to adjuvant 5-FU/leucovorin (5-FU/LV) with and without irinotecan [89]. MMR status was not predictive of OS in either arm. However, in the 5-FU/LV plus irinotecan arm, a significantly better 5-year DFS was observed in patients with MSI-H/dMMR tumors than in patients with MSS tumors (HR 0.76 vs. 0.59). This trend was not seen in patients treated with 5-FU/LV alone. Among all MSI-H/dMMR patients on study, adding irinotecan to 5-FU/LV seemed to improve DFS (HR 0.76 vs. 0.57 ), and although this finding was not statistically significant, no such trend was observed in MSS patients (HR 0.59 vs. 0.61). The prognostic effect seen with irinotecan in the CALBG 89803 study was not observed in the PETACC-3 trial [16,90]. Multivariable analysis revealed that MSI-H status was an independent prognostic variable independent of sex, T stage, and grade for RFS and OS. 
According to current guidelines, irinotecan is not recommended in the adjuvant setting. Therefore, although the CALGB 89803 trial results are clinically inapplicable, they suggest that MSI-H/dMMR CRCs have a unique biology that may affect prognosis even with different chemotherapy agents. Oxaliplatin, a platinum compound that causes DNA adducts and intra-strand cross-links between DNA base pairs, inhibition of DNA replication, and ultimately apoptosis, is commonly used in combination with 5-FU in CRC. Platinum agents, such as oxaliplatin, cisplatin, and carboplatin, interfere with the pMMR system, cause DNA damage, impair DNA repair, and ultimately result in apoptosis. dMMR confers resistance to cisplatin and carboplatin as cells can proliferate despite DNA damage from the chemotherapy [91]. However, unlike cisplatin and carboplatin, dMMR CRC cells in vitro were sensitive to oxaliplatin, and this was attributed to a unique, bulky 1,2-diaminocyclohexane ligand of oxaliplatin that prevents MMR complex binding, more effectively inhibits DNA synthesis, and ultimately results in apoptosis [92]. Subgroup analyses in retrospective human studies show that the addition of oxaliplatin to 5-FU may improve outcomes compared to 5-FU alone in dMMR CRCs, particularly in stage III disease. However, other studies did not reproduce these results [79,93]. It is possible that oxaliplatin and other cytotoxic agents offset potential 5-FU resistance in dMMR tumors, although more highly populated studies are required to prove this hypothesis. Although the mechanisms behind oxaliplatin and 5-FU synergism remain unclear, and interactions between oxaliplatin and dihydropyrimidine dehydrogenase (DPD) activity were not directly investigated in this study, one group hypothesized that oxaliplatin might downregulate DPD and decrease 5-FU catabolism [94].

Myriad studies suggest that the prognostic value of MSI/MMR status can be stratified based on the presence or absence of additional molecular markers. In the PETACC-3 trial-although the study only included adjuvant chemotherapy-treated patients-exploratory statistical models showed that stage III tumors with additional detected biomarkers such as MSI-H and simultaneously retained SMAD4 expression had comparable survival to stage IIA disease [16]. The authors suggested that with further validation using large multivariable analyses, molecular profiles, including MSI/MMR status, might contribute to prognostic assessment in stage II and III CRCs, as well as potentially determine those stage III patients that could be spared adjuvant chemotherapy. Watanabe et al. studied the molecular features of 460 high-risk stage II and stage III CRCs from two clinical trials (Eastern Cooperative Oncology Group protocol E2284 and protocol E2288), in which patients received fluorouracil-based adjuvant chemotherapy [77]. The authors reported a statistically significant improvement in 5-year DFS in patients with stage III CRCs that were MSI-H compared to MSS (64\% vs. $49 \%, p=0.02$ ). Five-year OS, however, was not different. Among patients with MSI-H CRCs, significant 5-year DFS ( $79 \%$ vs. $40 \%, p=0.007)$ and OS (74\% vs. $46 \%, p=0.04)$ advantages were noted in patients with a gene mutation in the type II receptor for TGF- $\beta 1$. These findings suggest that stage III MSI-H CRCs concurrently harboring TGF- $\beta 1$-mutations predict likelihood of survival in patients treated with adjuvant 5-FU-based chemotherapy, although the mechanism of the survival advantage is unclear. In a posthoc analysis of the CKVO 90-11 trial, almost 400 patients with stage III CRC were assessed for MSI as well as tumor protein 53 (TP53) mutations in exons 4 to 8 (the majority of mutations were in the DNA binding domain) and Kirsten rat sarcoma viral oncogene homolog (KRAS) mutations in exons 1 and 2. Both TP53 mutations and MSI-H were associated with a prolonged DFS in patients with 5-FU-based adjuvant treatment; however, in the multivariate analysis adjusted for tumor grade, histology, number of tumor-positive nodes, and depth of tumor invasion, only TP53 remained a statistically significant independent predictor of DFS [61].

Although there are promising data presented here concerning MSI status and its predictive value, findings are derived predominantly from retrospective analyses of a limited patient population. As such, further large prospective trials to study MSI/MMR status and combinations with other molecular markers, including but not limited to KRAS or $B R A F$, are required to understand their prognostic values better. While some in vitro studies suggest the efficacy of different chemotherapies vary depending on dMMR status, the clinical implications of these results have yet to be determined. 
Future prospective studies analyzing these biomarkers and patient outcomes following treatment with different chemotherapy regimens may help guide the choice of adjuvant therapy.

\section{KRAS Mutation}

KRAS is a proto-oncogene that transduces-through its GTPase activity-extracellular stimuli from the epidermal growth factor receptor (EGFR) in the nucleus, triggering cell growth, proliferation, differentiation, and survival $[95,96]$. The KRAS mutation is one of the most frequently mutated genes in CRC, found in up to $40-50 \%$ of cases [97]. Furthermore, similar to mutated APC and TP53, the KRAS mutation is a crucial step in CRC carcinogenesis [98]. Although the detection of mutations in KRAS in metastatic disease is essential before making therapeutic decisions [21,22], the analysis of these aberrations in patients with a nonmetastatic disease is not a standard of care, and they have no clear clinical role [52,99]. Only recently, Scott et al. used the National Cancer Database (NCDB) to analyze clinical features and outcomes of patients with KRAS-mutated nonmetastatic CRC [45]. In this retrospective study, KRAS mutations were more commonly found in tumors from African American patients and in right-sided primary tumors. Moreover, KRAS-mutated stage III tumors were associated with worse patient outcomes than KRAS wild-type (wt) tumors. This finding is in line with a later study showing that both codon 12 and 13 KRAS mutations are related to right-sided stage III colon tumors and inferior patient survival [46]. Of note, right-sided tumor location alone was attributed to shorter survival-after-recurrence and OS independent of the KRAS status [47]. A later study confirmed that codon 12 KRAS mutations were associated with an inferior OS; however, codon 13 KRAS mutations had no impact on survival [48]. Deng and colleagues showed that detection of KRAS alterations in tumors of patients not receiving adjuvant chemotherapy had a worse 3-year DFS than patients with wt tumors. On the other hand, other analyses could not show any prognostic implications of KRAS mutations in nonmetastatic CRC.

Neither the CALGB 89803 nor the PETACC-3 trials have demonstrated a prognostic effect of KRAS mutations in patients receiving adjuvant chemotherapy [7,51]. In an ancillary study of the PETACC-8 trial, KRAS mutations in exon 2 (codons 12 and 13) were examined in patients with stage III CRC receiving adjuvant chemotherapy [100]. In line with data derived from the PETACC-3 trial, mutations in exon 3 (codons 12 and 13) were not prognostic. However, KRAS exon 2 mutations were associated with shorter time to recurrence. In the prospective NCCTG N0147 trial, patients were enrolled before molecular testing for colon cancer was established as standard-of-care. However, tumors from more than 2700 stage III CRC patients were retrospectively tested for mutations in KRAS and BRAF, as well as MMR status, and their relationships to patient outcomes were assessed [50]. Patients with pMMR tumors and a concomitant BRAF or KRAS mutation had a shorter 5-year DFS compared to patients without these alterations. Consistent with these data, further studies showed that particularly patients with pMMR and KRAS mutations had reduced survival compared to patients with pMMR and KRAS wt or dMMR CRC $[53,101]$.

In summary, the prognostic value of KRAS mutations in nonmetastatic CRC remains debatable because of conflicting results from several studies. The current literature does not support the routine testing for KRAS in stage I-III CRCs. Study designs (mainly retrospective or posthoc analyses), tumor heterogeneity, primary tumor location, assessment of MMR, as well as adjuvant therapies received, could have influenced the prognostic value of KRAS mutations. Thus, to get a clear idea of the prognostic value of KRAS mutations, prospective trials investigating KRAS mutations stratified according to MMR and primary tumor location in the nonmetastatic setting are necessary.

\subsection{BRAF Gene Alteration}

The serine/threonine-protein kinase $B R A F$ acts as a downstream effector of EGFR/KRAS signaling and interacts with the MEK/ERK pathway [102]. Roughly $10 \%$ of all CRC tumors possess a BRAF mutation [103]. The most frequently reported alteration results in a valine-to-glutamic acid (V600E) that activates the MEK/ERK pathway [104]. BRAF mutated CRC correlates with dMMR/MSI-H, right-sided 
tumors, female sex, and poor outcome. Notably, BRAF mutations are mutually exclusive of KRAS mutations [54,55,105-107]. The negative prognostic effect of $B R A F$ was seen in several trials. In the PETACC-3 study, BRAF mutations were predictive of poor patient OS, particularly in the subpopulation of pMMR tumors, but were not prognostic for RFS [7]. In line with these results, the PETACC-8 trial showed that both BRAF and KRAS mutations are related to an inferior outcome in patients with pMMR but not for dMMR/MSI-H [55]. Several other studies confirmed that $B R A F$ is associated with a worse outcome, especially in the pMMR subpopulation of stage III CRC [52-54,56-60]. Now that we are routinely using therapeutics against $B R A F$-mutated CRC in the metastatic setting, it would be highly relevant to study the effect of these agents in the adjuvant setting [36].

In summary, BRAF mutations seem to predict a worse outcome in patients with resected stage III CRC, especially in the subgroup of patients with a proficient MMR system. As such, future trials should use BRAF and MMR as important stratification markers.

\subsection{TP53 Mutation}

The so-called "guardian of the genome" TP53 is a fundamental regulator of the cell cycle, apoptosis, and DNA repair [108]. Loss of function mutations in TP53 are frequently observed during tumorigenesis of several different cancer entities, particularly in CRC, where TP53 is a fundamental step during the adenoma-carcinoma sequence $[109,110]$. The impact of TP53 gene alterations on the prognosis of CRC patients in the adjuvant setting has been widely analyzed [52,111]. Several studies have shown that TP53 protein expression and gene mutations were associated with a poor outcome [61-65]. However, other studies could not replicate these results and found no correlation between TP53 alterations and survival [112-114]. The prospective ABCSG-90 trial analyzed the prognostic efficacy of TP53 in stage III CRC. TP53 gene alterations were significantly associated with a good prognosis in patients with N1 tumors receiving adjuvant 5-FU-based chemotherapy, whereas TP53 mutations in patients with N2 tumors were not prognostic [65]. However, one may argue that a TP53 mutation is less responsible for prognosis than the nodal status as nodal status is a robust predictive clinical marker. Some preclinical studies suggest p53 expression may be essential to 5-FU induced apoptosis and contribute to oxaliplatin-induced apoptosis, although other studies report conflicting results [115-117].

Varying study designs and analytical methods used may be the reason for these conflicting results in clinical studies. Although some studies used sequencing techniques, others used immunohistochemistry (IHC) to detect protein expression of p53. However, using p53 overexpression as an indicator of TP53 mutational status is weak because loss and gain of function mutations may lead to a loss of protein expression [118]. Furthermore, diagnostic antibodies used for the detection of p53 by IHC have varying sensitivity. Thus, further studies should focus on sequencing techniques to detect TP53 and to further elucidate its prognostic effect in nonmetastatic CRC.

\subsection{PIK3CA Gene Alteration}

PIK3CA mutations activate the PI3K/AKT/mTOR pathway that constitutively leads to tumor cell proliferation and survival, as well as multidrug resistance $[119,120]$. PIK3CA mutation prevalence is higher in right-sided, KRAS-mutated, and MSI CRC [121]. In a retrospective study, Jian and colleagues showed that simultaneous mutations in PIK3CA and TP53 are associated with poor survival in patients with stage III CRC compared to patients with wild type tumors [66]. However, single mutations in the PIK3CA gene did not affect outcome [122]. In the metastatic setting, PIK3CA gene alterations were correlated with primary resistance to chemotherapy and anti-EGFR therapy [123,124]. Recently, PIK3CA mutations have gained attention because, in May 2019, the US FDA approved a new PI3K-targeted therapeutic agent, alpelisib. Combination alpelisib and fulvestrant treatment yielded an impressive prolongation of PFS compared to fulvestrant monotherapy in patients with hormone-receptor-positive breast cancer [125]. For CRC patients, a phase I/II trial is currently ongoing, which is evaluating the efficacy of alpelisib in combination with encorafenib and cetuximab in the metastatic setting (NCT01719380). However, in the adjuvant setting, no study is presently planned 
or ongoing. Thus, with the currently available data, the prognostic and predictive value of PIK3CA remains unclear. Further analyses should focus on PIK3CA gene alterations in patients with stage III $\mathrm{CRC}$ receiving adjuvant chemotherapy since primary resistance to chemotherapy was described in the metastatic setting.

\subsection{APC Mutation}

Gene alterations in adenomatous-polyposis-coli $(A P C)$ is one of the most commonly found mutations in CRC [126]. APC is a key negative regulator of WNT signaling that results in activation of $\beta$-catenin and c-myc [127]. Its prognostic and predictive value in CRC remains inconclusive so far. Small retrospective studies showed that APC mutations are neither associated with survival nor with response to treatment in CRC [70-72]. On the other hand, Jorissen and colleagues showed that mutations in APC in MSS tumors had a favorable outcome compared to APC wild-type MSS tumors [69]. In contrast to these results, a further large retrospective study using targeted parallel sequencing revealed that $A P C$ mutations are associated with a worse survival in patients with stage III CRC treated with 5-FU [68]. As such, although APC mutations are one of the most relevant gene alterations in $\mathrm{CRC}$, the prognostic and predictive value remains unclear.

\section{Perspectives and Conclusions}

The heterogeneous molecular landscape of metastatic CRC has dramatically changed the treatment and prognosis of patients [21,22]. With the approval of anti-EGFR and anti-VEGF agents in the first-line setting, stratified by RAS and RAF, survival of more than 30 months can be achieved [128-130]. However, the use of genetic biomarkers for guiding treatment decisions in early-stage disease is not currently implemented because data about the prognostic and predictive value of KRAS, BRAF, TP53, $A P C$, and $P I K 3 C A$ remain inconsistent.

The MSI-H/dMMR status-contributing to a favorable immunogenic environment-is an established predictive biomarker for response to checkpoint inhibitor therapy in various cancers, including CRC [131]. Although improved responses with immunotherapy have been reported in patients with metastatic MSI-H/dMMR CRCs, these responses are not seen in the majority of MSS/pMMR CRCs. Numerous trials of combined immunotherapy with other agents aimed at "sensitizing" these tumors are ongoing [132,133].

Based on trials reporting improved outcomes with single or combination immunotherapy, these treatments are included in the NCCN guidelines as second-line therapy for patients with metastatic MSI-H/dMMR CRC. Furthermore, promising results from a recently presented phase III trial investigating the checkpoint inhibitor pembrolizumab in the first-line setting of patients with MSI-H/dMMR metastatic CRC have given rise to a new standard of care for this patient subset [30].

Immunotherapy's role in nonmetastatic CRC remains under investigation. In the ongoing phase II NICHE trial, investigators are evaluating its role in the neoadjuvant setting with early positive results [134]. The ongoing phase III ATOMIC trial (NCT02912559) is focused on the study of chemotherapy (modified FOLFOX) with or without immunotherapy (atezolizumab) in the adjuvant setting for dMMR stage III CRC [135]. Whether adjuvant immunotherapy improves outcomes or MSI/MMR status plays a predictive role in this setting has yet to be determined, pending the results of the ATOMIC trial and ideally more prospective adjuvant trials. Furthermore, there is evidence that tumor-intrinsic oncogenic signaling pathways also play a role in regulating the tumor microenvironment and immune system evasion [136,137]. For example, upregulation and activation of the $\beta$-catenin, STAT3, and the PI3K/AKT pathways were found to alter tumor T-cell infiltration and contribute to immune evasion when studied in various cancer types [136,138-141]. A study also demonstrated that oncogenic KRAS signaling is associated with increased immune evasion by upregulating programmed cell death ligand 1 (PD-L1) expression [142]. Even the renin-angiotensin system is thought to contribute to an immunosuppressive microenvironment, and while combining angiotensin-converting enzyme inhibitors with immunotherapy is a proposed therapeutic intervention, 
preclinical and clinical studies are lacking to date [143]. Further elucidation of these pathways and biomarker identifications may allow us to manipulate tumor immunotherapy responsiveness with combined therapeutic and "sensitizing" agents in the metastatic and adjuvant settings in the future.

Taken together, although molecular profiling changed how patients with CRC are managed and treated in the metastatic setting, the role of profiling in the adjuvant setting remains unclear. However, several studies are ongoing, and investigators will try to deliver new insights into the prognostic and predictive efficacy of molecular biomarkers in adjuvant therapy.

Author Contributions: R.M., A.S., and J.L.M. contributed to drafting, writing, and editing the review manuscript. R.M. contributed to making Tables 1-3, A.S. contributed to making Table 2, and R.M., A.S., and J.L.M. All contributed to editing and reviewing all tables. All authors have read and agreed to the published version of the manuscript.

Funding: This research received no external funding.

Acknowledgments: We would like to thank Marion L Hartley, for her valuable edits and suggestions during the composition of this manuscript.

Conflicts of Interest: No conflict of interest.

\section{References}

1. Baudrin, L.G.; Deleuze, J.-F.; How-Kit, A. Molecular and Computational Methods for the Detection of Microsatellite Instability in Cancer. Front. Oncol. 2018, 8. [CrossRef] [PubMed]

2. Salem, M.E.; Puccini, A.; Grothey, A.; Raghavan, D.; Goldberg, R.M.; Xiu, J.; Korn, W.M.; Weinberg, B.A.; Hwang, J.J.; Shields, A.F.; et al. Landscape of Tumor Mutation Load, Mismatch Repair Deficiency, and PD-L1 Expression in a Large Patient Cohort of Gastrointestinal Cancers. Mol. Cancer Res. 2018, 805-812. [CrossRef] [PubMed]

3. Lorenzi, M.; Amonkar, M.; Zhang, J.; Mehta, S.; Liaw, K.-L. Epidemiology of Microsatellite Instability High (MSI-H) and Deficient Mismatch Repair (dMMR) in Solid Tumors: A Structured Literature Review. J. Oncol. 2020, 2020, e1807929. [CrossRef]

4. Oliveira, A.F.; Bretes, L.; Furtado, I. Review of PD-1/PD-L1 Inhibitors in Metastatic dMMR/MSI-H Colorectal Cancer. Front. Oncol. 2019, 9. [CrossRef] [PubMed]

5. Shukla, N.; Abrha, A.; Longacre, T.A.; Koff, R.; Ford, J.M.; Fisher, G.A.; Haraldsdottir, S. Prevalence and molecular etiology of mismatch repair deficiency among gastrointestinal cancers. J. Clin. Oncol. 2019, 37, 215. [CrossRef]

6. Carethers, J.M. Hereditary, sporadic and metastatic colorectal cancer are commonly driven by specific spectrums of defective DNA mismatch repair components. Trans. Am. Clin. Climatol. Assoc. 2016, 127, 81-97. [PubMed]

7. Roth, A.D.; Tejpar, S.; Delorenzi, M.; Yan, P.; Fiocca, R.; Klingbiel, D.; Dietrich, D.; Biesmans, B.; Bodoky, G.; Barone, C.; et al. Prognostic role of KRAS and BRAF in stage II and III resected colon cancer: Results of the translational study on the PETACC-3, EORTC 40993, SAKK 60-00 trial. J. Clin. Oncol. 2010, 28, 466-474. [CrossRef]

8. Malesci, A.; Laghi, L.; Bianchi, P.; Delconte, G.; Randolph, A.; Torri, V.; Carnaghi, C.; Doci, R.; Rosati, R.; Montorsi, M.; et al. Reduced likelihood of metastases in patients with microsatellite-unstable colorectal cancer. Clin. Cancer Res. 2007, 13, 3831-3839. [CrossRef]

9. Buckowitz, A.; Knaebel, H.-P.; Benner, A.; Bläker, H.; Gebert, J.; Kienle, P.; Doeberitz, M.V.K.; Kloor, M. Microsatellite instability in colorectal cancer is associated with local lymphocyte infiltration and low frequency of distant metastases. Br. J. Cancer 2005, 92, 1746-1753. [CrossRef]

10. Benatti, P.; Gafà, R.; Barana, D.; Marino, M.; Scarselli, A.; Pedroni, M.; Maestri, I.; Guerzoni, L.; Roncucci, L.; Menigatti, M.; et al. Microsatellite instability and colorectal cancer prognosis. Clin. Cancer Res. 2005, 11, 8332-8340. [CrossRef]

11. Halpern, N.; Goldberg, Y.; Kadouri, L.; Duvdevani, M.; Hamburger, T.; Peretz, T.; Hubert, A. Clinical course and outcome of patients with high-level microsatellite instability cancers in a real-life setting: A retrospective analysis. OncoTargets Ther. 2017, 10, 1889-1896. [CrossRef] [PubMed] 
12. Gray, R.; Quirke, P.; Handley, K.; Lopatin, M.; Magill, L.; Baehner, F.L.; Beaumont, C.; Clark-Langone, K.M.; Yoshizawa, C.N.; Lee, M.; et al. Validation study of a quantitative multigene reverse transcriptase-polymerase chain reaction assay for assessment of recurrence risk in patients with stage II colon cancer. J. Clin. Oncol. 2011, 29, 4611-4619. [CrossRef] [PubMed]

13. Popat, S.; Hübner, R.; Houlston, R.S. Systematic review of microsatellite instability and colorectal cancer prognosis. J. Clin. Oncol. 2005, 23, 609-618. [CrossRef] [PubMed]

14. Tejpar, S.; Bosman, F.; Delorenzi, M.; Fiocca, R.; Yan, P.; Klingbiel, D.; Dietrich, D.; Van Cutsem, E.; Labianca, R.; Roth, A. Microsatellite instability (MSI) in stage II and III colon cancer treated with 5FU-LV or 5FU-LV and irinotecan (PETACC 3-EORTC 40993-SAKK 60/00 trial). J. Clin. Oncol. 2009, 27, 4001. [CrossRef]

15. Klingbiel, D.; Saridaki, Z.; Roth, A.D.; Bosman, F.T.; Delorenzi, M.; Tejpar, S. Prognosis of stage II and III colon cancer treated with adjuvant 5-fluorouracil or FOLFIRI in relation to microsatellite status: Results of the PETACC-3 trial. Ann. Oncol. 2015, 26, 126-132. [CrossRef] [PubMed]

16. Roth, A.; Delorenzi, M.; Tejpar, S.; Yan, P.; Klingbiel, D.; Fiocca, R.; D'Ario, G.; Cisar, L.; Labianca, R.; Cunningham, D.; et al. Integrated analysis of molecular and clinical prognostic factors in stage II/III colon cancer. J. Natl. Cancer Inst. 2012, 104, 1635-1646. [CrossRef]

17. Petrelli, F.; Ghidini, M.; Cabiddu, M.; Pezzica, E.; Corti, D.; Turati, L.; Costanzo, A.; Varricchio, A.; Ghidini, A.; Barni, S.; et al. Microsatellite Instability and Survival in Stage II Colorectal Cancer: A Systematic Review and Meta-analysis. Anticancer Res. 2019, 39, 6431-6441. [CrossRef]

18. Böckelman, C.; Engelmann, B.E.; Kaprio, T.; Hansen, T.; Glimelius, B. Risk of recurrence in patients with colon cancer stage II and III: A systematic review and meta-analysis of recent literature. Acta Oncol. 2014, 54, 5-16. [CrossRef]

19. Bender, U.; Rho, Y.; Barrera, I.; Aghajanyan, S.; Acoba, J.; Kavan, P. Adjuvant therapy for stages II and III colon cancer: Risk stratification, treatment duration, and future directions. Curr. Oncol. 2019, 26, S43-S52. [CrossRef]

20. Meyers, B.M.; Cosby, R.; Quereshy, F.; Jonker, D. Adjuvant systemic chemotherapy for stages II and III colon cancer after complete resection: A clinical practice guideline. Curr. Oncol. 2016, 23, 418-424. [CrossRef]

21. National Comprehensive Cancer Network, Colon Cancer (Version 3.2020). Available online: https://www. nccn.org/professionals/physician_gls/pdf/colon.pdf (accessed on 9 May 2020).

22. Early Colon Cancer|ESMO. Available online: https://www.esmo.org/guidelines/gastrointestinal-cancers/ early-colon-cancer (accessed on 9 May 2020).

23. Ribic, C.M.; Sargent, D.; Moore, M.J.; Thibodeau, S.N.; French, A.J.; Goldberg, R.M.; Hamilton, S.R.; Laurent-Puig, P.; Gryfe, R.; Shepherd, L.E.; et al. Tumor microsatellite-instability status as a predictor of benefit from fluorouracil-based adjuvant chemotherapy for colon cancer. N. Engl. J. Med. 2003, 349, 247-257. [CrossRef] [PubMed]

24. Sargent, D.; Marsoni, S.; Monges, G.; Thibodeau, S.N.; Labianca, R.; Hamilton, S.R.; French, A.J.; Kabat, B.; Foster, N.R.; Torri, V.; et al. Defective mismatch repair as a predictive marker for lack of efficacy of fluorouracil-based adjuvant therapy in colon cancer. J. Clin. Oncol. 2010, 28, 3219-3226. [CrossRef] [PubMed]

25. Zhang, N.; Yin, Y.; Xu, S.-J.; Chen, W.-S. 5-Fluorouracil: Mechanisms of Resistance and Reversal Strategies. Molecules 2008, 13, 1551-1569. [CrossRef] [PubMed]

26. Meyers, M.; Wagner, M.W.; Hwang, H.S.; Kinsella, T.J.; Boothman, D.A. Role of the hMLH1 DNA mismatch repair protein in fluoropyrimidine-mediated cell death and cell cycle responses. Cancer Res. 2001, 61, 5193-5201.

27. Carethers, J.M.; Chauhan, D.P.; Fink, D.; Nebel, S.; Bresalier, R.S.; Howell, S.B.; Boland, C.R. Mismatch repair proficiency and in vitro response to 5-fluorouracil. Gastroenterology 1999, 117, 123-131. [CrossRef]

28. Arnold, C.N.; Goel, A.; Boland, C.R. Role of hMLH1 promoter hypermethylation in drug resistance to 5-fluorouracil in colorectal cancer cell lines. Int. J. Cancer 2003, 106, 66-73. [CrossRef]

29. Kawakami, H.; Zaanan, A.; Sinicrope, F. MSI testing and its role in the management of colorectal cancer. Curr. Treat. Options Oncol. 2015, 16, 30. [CrossRef]

30. Andre, T.; Shiu, K.-K.; Kim, T.W.; Jensen, B.V.; Jensen, L.H.; Punt, C.J.A.; Smith, D.M.; Garcia-Carbonero, R.; Benavides, M.; Gibbs, P.; et al. Pembrolizumab versus chemotherapy for microsatellite instability-high/mismatch repair deficient metastatic colorectal cancer: The phase 3 KEYNOTE-177 Study. J. Clin. Oncol. 2020, 38, LBA4. [CrossRef] 
31. Lièvre, A.; Bachet, J.-B.; Boige, V.; Cayre, A.; Le Corre, D.; Buc, E.; Ychou, M.; Bouché, O.; Landi, B.; Louvet, C.; et al. KRAS Mutations as an Independent Prognostic Factor in Patients With Advanced Colorectal Cancer Treated With Cetuximab. J. Clin. Oncol. 2008, 26, 374-379. [CrossRef]

32. Amado, R.G.; Wolf, M.; Peeters, M.; Van Cutsem, E.; Siena, S.; Freeman, D.J.; Juan, T.; Sikorski, R.; Suggs, S.; Radinsky, R.; et al. Wild-type KRAS is required for panitumumab efficacy in patients with metastatic colorectal cancer. J. Clin. Oncol. 2008, 26, 1626-1634. [CrossRef]

33. Douillard, J.Y.; Oliner, K.S.; Siena, S.; Tabernero, J.; Burkes, R.; Barugel, M.; Humblet, Y.; Bodoky, G.; Cunningham, D.; Jassem, J.; et al. Panitumumab-FOLFOX4 Treatment and RAS Mutations in Colorectal Cancer. N. Engl. J. Med. 2013, 369, 1023-1034. [CrossRef] [PubMed]

34. Di Nicolantonio, F.; Martini, M.; Molinari, F.; Sartore-Bianchi, A.; Arena, S.; Saletti, P.; De Dosso, S.; Mazzucchelli, L.; Frattini, M.; Siena, S.; et al. Wild-Type BRAF Is Required for Response to Panitumumab or Cetuximab in Metastatic Colorectal Cancer. J. Clin. Oncol. 2008, 26, 5705-5712. [CrossRef] [PubMed]

35. Bokemeyer, C.; Van Cutsem, E.; Rougier, P.; Ciardiello, F.; Heeger, S.; Schlichting, M.; Celik, I.; Köhne, C.-H. Addition of cetuximab to chemotherapy as first-line treatment for KRAS wild-type metastatic colorectal cancer: Pooled analysis of the CRYSTAL and OPUS randomised clinical trials. Eur. J. Cancer 2012, 48, 1466-1475. [CrossRef] [PubMed]

36. Kopetz, S.; Grothey, A.; Yaeger, R.; Van Cutsem, E.; Desai, J.; Yoshino, T.; Wasan, H.; Ciardiello, F.; Loupakis, F.; Hong, Y.S.; et al. Tabernero, Encorafenib, Binimetinib, and Cetuximab in BRAF V600E-Mutated Colorectal Cancer. N. Engl. J. Med. 2019, 381, 1632-1643. [CrossRef]

37. Cenaj, O.; Ligon, A.H.; Hornick, J.L.; Sholl, L.M. Detection of ERBB2 Amplification by Next-Generation Sequencing Predicts HER2 Expression in Colorectal Carcinoma. Am. J. Clin. Pathol. 2019, 152, 97-108. [CrossRef] [PubMed]

38. Valtorta, E.; Martino, C.; Sartore-Bianchi, A.; Penaullt-Llorca, F.; Viale, G.; Risio, M.; Rugge, M.; Grigioni, W.; Bencardino, K.; Lonardi, S.; et al. Assessment of a HER2 scoring system for colorectal cancer: Results from a validation study. Mod. Pathol. 2015, 28, 1481-1491. [CrossRef]

39. Sartore-Bianchi, A.; Trusolino, L.; Martino, C.; Bencardino, K.; Lonardi, S.; Bergamo, F.; Zagonel, V.; Leone, F.; Depetris, I.; Martinelli, E.; et al. Dual-targeted therapy with trastuzumab and lapatinib in treatment-refractory, KRAS codon 12/13 wild-type, HER2-positive metastatic colorectal cancer (HERACLES): A proof-of-concept, multicentre, open-label, phase 2 trial. Lancet Oncol. 2016, 17, 738-746. [CrossRef]

40. Solomon, J.P.; Hechtman, J.F. Detection of NTRK Fusions: Merits and Limitations of Current Diagnostic Platforms. Cancer Res. 2019. [CrossRef]

41. Solomon, J.P.; Linkov, I.; Rosado, A.; Mullaney, K.; Rosen, E.Y.; Frosina, D.; Jungbluth, A.A.; Zehir, A.; Benayed, R.; Drilon, A.; et al. NTRK fusion detection across multiple assays and 33,997 cases: Diagnostic implications and pitfalls. Mod. Pathol. 2019, 33, 38-46. [CrossRef]

42. Hechtman, J.; Benayed, R.; Hyman, D.M.; Drilon, A.; Zehir, A.; Frosina, D.; Arcila, M.E.; Dogan, S.; Klimstra, D.S.; Ladanyi, M.; et al. Pan-Trk Immunohistochemistry Is an Efficient and Reliable Screen for the Detection of NTRK Fusions. Am. J. Surg. Pathol. 2017, 41, 1547-1551. [CrossRef]

43. Demetri, G.; Paz-Ares, L.; Farago, A.; Liu, S.; Chawla, S.; Tosi, D.; Kim, E.; Blakely, C.; Krauss, J.; Sigal, D.; et al. Efficacy and safety of entrectinib in patients with NTRK fusion-positive tumours: Pooled analysis of STARTRK-2, STARTRK-1, and ALKA-372-001. Ann. Oncol. 2018, 29, ix175. [CrossRef]

44. Drilon, A.E.; Laetsch, T.W.; Kummar, S.; Dubois, S.G.; Lassen, U.N.; Demetri, G.D.; Nathenson, M.; Doebele, R.C.; Farago, A.F.; Pappo, A.S.; et al. Efficacy of Larotrectinib in TRK Fusion-Positive Cancers in Adults and Children. N. Engl. J. Med. 2018, 378, 731-739. [CrossRef] [PubMed]

45. Scott, A.; Goffredo, P.; Ginader, T.; Hrabe, J.; Gribovskaja-Rupp, I.; Kapadia, M.R.; Weigel, R.J.; Hassan, I. The Impact of KRAS Mutation on the Presentation and Prognosis of Non-Metastatic Colon Cancer: An Analysis from the National Cancer Database. J. Gastrointest. Surg. 2020. [CrossRef] [PubMed]

46. Yoon, H.H.; Tougeron, D.; Shi, Q.; Alberts, S.R.; Mahoney, M.R.; Nelson, G.D.; Nair, S.G.; Thibodeau, S.N.; Goldberg, R.M.; Sargent, D.; et al. Sinicrope, for the Alliance for Clinical Trials in Oncology, KRAS Codon 12 and 13 Mutations in Relation to Disease-Free Survival in BRAF-Wild-Type Stage III Colon Cancers from an Adjuvant Chemotherapy Trial (N0147 Alliance). Clin. Cancer Res. 2014, 20, 3033-3043. [CrossRef]

47. Taieb, J.; Kourie, H.R.; Emile, J.-F.; Le Malicot, K.; Balogoun, R.; Tabernero, J.; Mini, E.; Folprecht, G.; Van Laethem, J.-L.; Mulot, C.; et al. Laurent-Puig, Association of Prognostic Value of Primary Tumor Location in Stage III Colon Cancer With RAS and BRAF Mutational Status. JAMA Oncol. 2018, 4, e173695. [CrossRef] 
48. Andreyev, H.J.N.; Norman, A.R.; Cunningham, D.; Oates, J.; Dix, B.R.; Iacopetta, B.J.; Young, J.; Walsh, T.; Ward, R.; Hawkins, N.; et al. Kirsten ras mutations in patients with colorectal cancer: The "RASCAL II" study. Br. J. Cancer 2001, 85, 692-696. [CrossRef]

49. Deng, Y.; Wang, L.; Tan, S.; Kim, G.P.; Dou, R.; Chen, D.; Cai, Y.; Fu, X.; Wang, L.; Zhu, J.; et al. KRAS as a predictor of poor prognosis and benefit from postoperative FOLFOX chemotherapy in patients with stage II and III colorectal cancer. Mol. Oncol. 2015, 9, 1341-1347. [CrossRef]

50. Sinicrope, F.; Shi, Q.; Smyrk, T.C.; Thibodeau, S.N.; Dienstmann, R.; Guinney, J.; Bot, B.M.; Tejpar, S.; Delorenzi, M.; Goldberg, R.M.; et al. Molecular markers identify subtypes of stage III colon cancer associated with patient outcomes. Gastroenterology 2014, 148, 88-99. [CrossRef]

51. Ogino, S.; Meyerhardt, J.A.; Irahara, N.; Niedzwiecki, N.; Hollis, N.; Saltz, L.B.; Mayer, R.J.; Schaefer, P.; Whittom, R.; Hantel, A.; et al. Fuchs, for the Cancer and Leukemia Group B, North Central Cancer Treatment Group, Canadian Cancer Society Research Institute, Southwest Oncology Group, KRAS Mutation in Stage III Colon Cancer and Clinical Outcome Following Intergroup Trial CALGB 89803. Clin. Cancer Res. 2009, 15, 7322-7329. [CrossRef]

52. Tejpar, S.; Bertagnolli, M.; Bosman, F.; Lenz, H.-J.; Garraway, L.; Waldman, F.; Warren, R.; Bild, A.; Collins-Brennan, D.; Hahn, H.; et al. Prognostic and predictive biomarkers in resected colon cancer: Current status and future perspectives for integrating genomics into biomarker discovery. Oncologist 2010, 15, 390-404. [CrossRef]

53. Taieb, J.; Le Malicot, K.; Shi, Q.; Penault-Llorca, F.; Bouché, O.; Tabernero, J.; Mini, E.; Goldberg, R.M.; Folprecht, G.; Van Laethem, J.L.; et al. Prognostic Value of BRAF and KRAS Mutations in MSI and MSS Stage III Colon Cancer. J. Natl. Cancer Inst. 2016, 109. [CrossRef]

54. French, A.J.; Sargent, D.J.; Burgart, L.J.; Foster, N.R.; Kabat, B.F.; Goldberg, R.; Shepherd, L.; Windschitl, H.E.; Thibodeau, S.N. Prognostic significance of defective mismatch repair and BRAF V600E in patients with colon cancer. Clin. Cancer Res. 2008, 14, 3408-3415. [CrossRef] [PubMed]

55. Taïeb, J.; Zaanan, A.; Le Malicot, K.; Julié, C.; Blons, H.; Mineur, L.; Bennouna, J.; Tabernero, J.; Mini, E.; Folprecht, G.; et al. Laurent-Puig, Prognostic Effect of BRAF and KRAS Mutations in Patients with Stage III Colon Cancer Treated With Leucovorin, Fluorouracil, and Oxaliplatin With or Without Cetuximab: A Post Hoc Analysis of the PETACC-8 Trial. JAMA Oncol. 2016, 2, 643-653. [CrossRef] [PubMed]

56. Ardekani, G.S.; Jafarnejad, S.M.; Tan, L.; Saeedi, A.; Li, G. The Prognostic Value of BRAF Mutation in Colorectal Cancer and Melanoma: A Systematic Review and Meta-Analysis. PLoS ONE 2012, 7, e47054. [CrossRef]

57. Samowitz, W.S.; Sweeney, C.; Herrick, J.; Albertsen, H.; Levin, T.R.; Murtaugh, M.A.; Wolff, R.K.; Slattery, M.L. Poor survival associated with the BRAF V600E mutation in microsatellite-stable colon cancers. Cancer Res. 2005, 65, 6063-6069. [CrossRef]

58. Yokota, T.; Ura, T.; Shibata, N.; Takahari, D.; Shitara, K.; Nomura, M.; Kondo, C.; Mizota, A.; Utsunomiya, S.; Muro, K.; et al. BRAF mutation is a powerful prognostic factor in advanced and recurrent colorectal cancer. Br. J. Cancer 2011, 104, 856-862. [CrossRef]

59. Richman, S.D.; Seymour, M.T.; Chambers, P.; Elliott, F.; Daly, C.L.; Meade, A.M.; Taylor, G.; Barrett, J.H.; Quirke, P. KRAS and BRAF mutations in advanced colorectal cancer are associated with poor prognosis but do not preclude benefit from oxaliplatin or irinotecan: Results from the MRC FOCUS trial. J. Clin. Oncol. 2009, 27, 5931-5937. [CrossRef]

60. Alwers, E.; Bläker, H.; Walter, V.; Jansen, L.; Kloor, M.; Arnold, A.; Sieber-Frank, J.; Herpel, E.; Tagscherer, K.E.; Roth, W.; et al. External validation of molecular subtype classifications of colorectal cancer based on microsatellite instability, CIMP, BRAF and KRAS. BMC Cancer 2019, 19, 681. [CrossRef] [PubMed]

61. Westra, J.L.; Schaapveld, M.; Hollema, H.; De Boer, J.P.; Kraak, M.M.; De Jong, D.; Ter Elst, A.; Mulder, N.H.; Buys, C.H.; Hofstra, R.; et al. Determination of TP53 mutation is more relevant than microsatellite instability status for the prediction of disease-free survival in adjuvant-treated stage III colon cancer patients. J. Clin. Oncol. 2005, 23, 5635-5643. [CrossRef]

62. Elsaleh, H.; Powell, B.; McCaul, K.; Grieu, F.; Grant, R.; Joseph, D.; Iacopetta, B. P53 alteration and microsatellite instability have predictive value for survival benefit from chemotherapy in stage III colorectal carcinoma. Clin. Cancer Res 2001, 7, 1343-1349. 
63. Russo, A.; Bazan, V.; Iacopetta, B.; Kerr, D.; Soussi, T.; Gebbia, N. TP53-CRC Collaborative Study Group, The TP53 colorectal cancer international collaborative study on the prognostic and predictive significance of p53 mutation: Influence of tumor site, type of mutation, and adjuvant treatment. J. Clin. Oncol. 2005, 23, 7518-7528. [CrossRef] [PubMed]

64. Ahnen, D.J.; Feigl, P.; Quan, G.; Fenoglio-Preiser, C.; Lovato, L.C.; Bunn, P.A.; Stemmerman, G.; Wells, J.D.; Macdonald, J.S.; Meyskens, F.L. Ki-ras mutation and p53 overexpression predict the clinical behavior of colorectal cancer: A Southwest Oncology Group study. Cancer Res. 1998, 58, 1149-1158. [PubMed]

65. Kandioler, D.; Mittlböck, M.; Kappel, S.; Puhalla, H.; Herbst, F.; Langner, C.; Wolf, B.; Tschmelitsch, J.; Schippinger, W.; Steger, G.; et al. TP53 Mutational Status and Prediction of Benefit from Adjuvant 5-Fluorouracil in Stage III Colon Cancer Patients. EBioMedicine 2015, 2, 825-830. [CrossRef] [PubMed]

66. Li, A.-J.; Li, H.-G.; Tang, E.-J.; Wu, W.; Chen, Y.; Jiang, H.-H.; Lin, M.-B.; Yin, L. PIK3CA and TP53 mutations predict overall survival of stage II/III colorectal cancer patients. World J. Gastroenterol. 2018, 24, 631-640. [CrossRef]

67. Jover, R.; Zapater, P.; Castells, A.; Llor, X.; Andreu, M.; Cubiella, J.; Piñol, V.; Xicola, R.M.; Bujanda, L.; Reñé, J.M.; et al. Gastrointestinal Oncology Group of the Spanish Gastroenterological Association, Mismatch repair status in the prediction of benefit from adjuvant fluorouracil chemotherapy in colorectal cancer. Gut 2006, 55, 848-855. [CrossRef]

68. Broek, E.V.D.; Krijgsman, O.; Sie, D.; Tijssen, M.; Mongera, S.; Van De Wiel, M.A.; Belt, E.J.T.; Uil, S.H.D.; Bril, H.; Stockmann, H.B.; et al. Genomic profiling of stage II and III colon cancers reveals APC mutations to be associated with survival in stage III colon cancer patients. Oncotarget 2016, 7, 73876-73887. [CrossRef]

69. Jorissen, R.N.; Christie, M.; Mouradov, D.; Sakthianandeswaren, A.; Li, S.; Love, C.; Xu, Z.-Z.; Molloy, P.; Jones, I.T.; McLaughlin, S.; et al. Wild-type APC predicts poor prognosis in microsatellite-stable proximal colon cancer. Br. J. Cancer 2015, 113, 979-988. [CrossRef]

70. Dix, B.R.; Robbins, P.; Soong, R.; Jenner, D.; House, A.K.; Iacopetta, B.J. The common molecular genetic alterations in Dukes' B and C colorectal carcinomas are not short-term prognostic indicators of survival. Int. J. Cancer 1994, 59, 747-751. [CrossRef]

71. Conlin, A.; Smith, G.; Carey, F.A.; Wolf, C.R.; Steele, R.J. The prognostic significance of K-ras, p53, and APC mutations in colorectal carcinoma. Gut 2005, 54, 1283-1286. [CrossRef]

72. Hsieh, J.-S.; Lin, S.-R.; Chang, M.-Y.; Chen, F.-M.; Lu, C.-Y.; Huang, T.-J.; Huang, Y.-S.; Huang, C.-J.; Wang, J.-Y. APC, K-ras, and p53 Gene Mutations in Colorectal Cancer Patients: Correlation to Clinicopathologic Features and Postoperative Surveillance. Am. Surg. 2005, 71, 336-343. [CrossRef]

73. Hutchins, G.; Southward, K.; Handley, K.; Magill, L.; Beaumont, C.; Stahlschmidt, J.; Richman, S.; Chambers, P.; Seymour, M.; Kerr, D.; et al. Value of Mismatch Repair, KRAS, and BRAF Mutations in Predicting Recurrence and Benefits from Chemotherapy in Colorectal Cancer. J. Clin. Oncol. 2011, 29, 1261-1270. [CrossRef] [PubMed]

74. Koenig, J.L.; Toesca, D.A.; Harris, J.P.; Tsai, C.J.; Haraldsdottir, S.; Lin, A.Y.; Pollom, E.L.; Chang, D.T. Microsatellite Instability and Adjuvant Chemotherapy in Stage II Colon Cancer. Am. J. Clin. Oncol. 2019, 42, 573-580. [CrossRef] [PubMed]

75. Kim, J.E.; Hong, Y.S.; Kim, H.J.; Kim, K.-P.; Kim, S.Y.; Lim, S.-B.; Park, I.J.; Kim, C.W.; Yoon, Y.S.; Yu, C.S.; et al. Microsatellite Instability was not Associated with Survival in Stage III Colon Cancer Treated with Adjuvant Chemotherapy of Oxaliplatin and Infusional 5-Fluorouracil and Leucovorin (FOLFOX). Ann. Surg. Oncol. 2017, 24, 1289-1294. [CrossRef] [PubMed]

76. Tan, W.J.; Hamzah, J.L.; Acharyya, S.; Foo, F.J.; Lim, K.H.; Tan, I.B.H.; Tang, C.L.; Chew, M.H. Evaluation of Long-Term Outcomes of Microsatellite Instability Status in an Asian Cohort of Sporadic Colorectal Cancers. J. Gastrointest. Cancer 2017, 49, 311-318. [CrossRef]

77. Watanabe, T.; Wu, T.-T.; Catalano, P.J.; Ueki, T.; Satriano, R.; Haller, D.G.; Benson, A.B.; Hamilton, S.R. Molecular predictors of survival after adjuvant chemotherapy for colon cancer. N. Engl. J. Med. 2001, 344, 1196-1206. [CrossRef]

78. Bertagnolli, M.M.; Redston, M.; Compton, C.C.; Niedzwiecki, D.; Mayer, R.J.; Goldberg, R.M.; Colacchio, T.A.; Saltz, L.B.; Warren, R.S. Microsatellite instability and loss of heterozygosity at chromosomal location 18q: Prospective evaluation of biomarkers for stages II and III colon cancer-A study of CALGB 9581 and 89803. J. Clin. Oncol. 2011, 29, 3153-3162. [CrossRef] 
79. Tougeron, D.; Mouillet, G.; Trouilloud, I.; LeComte, T.; Coriat, R.; Aparicio, T.; Guetz, G.D.; Lécaille, C.; Artru, P.; Sickersen, G.; et al. Efficacy of Adjuvant Chemotherapy in Colon Cancer With Microsatellite Instability: A Large Multicenter AGEO Study. J. Natl. Cancer Inst. 2016, 108. [CrossRef]

80. Zaanan, A.; Cuilliere-Dartigues, P.; Guilloux, A.; Parc, Y.; Louvet, C.; De Gramont, A.; Tiret, E.; Dumont, S.; Gayet, B.; Validire, P.; et al. Impact of p53 expression and microsatellite instability on stage III colon cancer disease-free survival in patients treated by 5 -fluorouracil and leucovorin with or without oxaliplatin. Ann. Oncol. 2010, 21, 772-780. [CrossRef]

81. Benson, A.B.; Schrag, D.; Somerfield, M.R.; Cohen, A.M.; Figueredo, A.; Flynn, P.J.; Krzyzanowska, M.K.; Maroun, J.; McAllister, P.; Van Cutsem, E.; et al. American Society of Clinical Oncology recommendations on adjuvant chemotherapy for stage II colon cancer. J. Clin. Oncol. 2004, 22, 3408-3419. [CrossRef]

82. Gill, S.; Loprinzi, C.L.; Sargent, D.; Thomé, S.D.; Alberts, S.R.; Haller, D.G.; Benedetti, J.; Francini, G.; Shepherd, L.E.; Seitz, J.F.; et al. Pooled analysis of fluorouracil-based adjuvant therapy for stage II and III colon cancer: Who benefits and by how much? J. Clin. Oncol. 2004, 22, 1797-1806. [CrossRef]

83. Koi, M.; Umar, A.; Chauhan, D.P.; Cherian, S.P.; Carethers, J.M.; Kunkel, T.A.; Boland, C.R. Human chromosome 3 corrects mismatch repair deficiency and microsatellite instability and reduces $\mathrm{N}$-methyl-N'-nitro-N-nitrosoguanidine tolerance in colon tumor cells with homozygous hMLH1 mutation. Cancer Res. 1994, 54, 4308-4312. [PubMed]

84. Pocard, M.; Bras-Gonçalves, R.; Hamelin, R.; Northover, J.; Poupon, M.F. Response to 5-fluorouracil of orthotopically xenografted human colon cancers with a microsatellite instability: Influence of P53 status. Anticancer Res. 2000, 20, 85-90. [PubMed]

85. Fujita, K.-I.; Kubota, Y.; Ishida, H.; Sasaki, Y. Irinotecan, a key chemotherapeutic drug for metastatic colorectal cancer. World J. Gastroenterol. 2015, 21, 12234-12248. [CrossRef]

86. Bras-Gonçalves, R.A.; Rosty, C.; Laurent-Puig, P.; Soulié, P.; Dutrillaux, B.; Poupon, M.-F. Sensitivity to CPT-11 of xenografted human colorectal cancers as a function of microsatellite instability and p53 status. $\mathrm{Br}$. J. Cancer 2000, 82, 913-923. [CrossRef]

87. Vilar, E.; Scaltriti, M.; Balmaña, J.; Saura, C.; Guzmán, M.; Arribas, J.; Baselga, J.; Tabernero, J. Microsatellite instability due to hMLH1 deficiency is associated with increased cytotoxicity to irinotecan in human colorectal cancer cell lines. Br. J. Cancer 2008, 99, 1607-1612. [CrossRef]

88. Koh, K.H.; Kang, H.J.; Li, L.S.; Kim, N.-G.; You, K.T.; Yang, E.; Kim, H.; Kim, H.J.; Yun, C.-O.; Kim, K.-S.; et al. Impaired nonhomologous end-joining in mismatch repair-deficient colon carcinomas. Lab. Investig. 2005, 85, 1130-1138. [CrossRef]

89. Bertagnolli, M.M.; Niedzwiecki, D.; Compton, C.C.; Hahn, H.P.; Hall, M.; Damas, B.; Jewell, S.D.; Mayer, R.J.; Goldberg, R.M.; Saltz, L.B.; et al. Microsatellite instability predicts improved response to adjuvant therapy with irinotecan, fluorouracil, and leucovorin in stage III colon cancer: Cancer and Leukemia Group B Protocol 89803. J. Clin. Oncol. 2009, 27, 1814-1821. [CrossRef]

90. Van Cutsem, E.; Labianca, R.; Bodoky, G.; Barone, C.; Aranda, E.; Nordlinger, B.; Topham, C.; Tabernero, J.; André, T.; Sobrero, A.F.; et al. Randomized phase III trial comparing biweekly infusional fluorouracil/leucovorin alone or with irinotecan in the adjuvant treatment of stage III colon cancer: PETACC-3. J. Clin. Oncol. 2009, 27, 3117-3125. [CrossRef]

91. Aebi, S.; Kurdi-Haidar, B.; Gordon, R.; Cenni, B.; Zheng, H.; Fink, D.; Christen, R.D.; Boland, C.R.; Koi, M.; Fishel, R.; et al. Loss of DNA Mismatch Repair in Acquired Resistance to Cisplatin. Cancer Res. 1996, 56, 3087-3090.

92. Raymond, E.; Chaney, S.G.; Taamma, A.; Cvitkovic, E. Oxaliplatin: A review of preclinical and clinical studies. Ann. Oncol. 1998, 9, 1053-1071. [CrossRef]

93. Gavin, P.G.; Colangelo, L.H.; Fumagalli, D.; Tanaka, N.; Remillard, M.Y.; Yothers, G.; Kim, C.; Taniyama, Y.; Kim, S.I.; Choi, H.J.; et al. Mutation Profiling and Microsatellite Instability in Stage II and III Colon Cancer: An Assessment of Their Prognostic and Oxaliplatin Predictive Value. Clin. Cancer Res. 2012, 18, 6531-6541. [CrossRef]

94. Fischel, J.L.; Formento, P.; Ciccolini, J.; Rostagno, P.; Etienne, M.C.; Catalin, J.; Milano, G. Impact of the oxaliplatin-5 fluorouracil-folinic acid combination on respective intracellular determinants of drug activity. Br. J. Cancer 2002, 86, 1162-1168. [CrossRef] [PubMed]

95. Prior, I.; Lewis, K.; Mattos, C. A comprehensive survey of Ras mutations in cancer. Cancer Res. 2012, 72, 2457-2467. [CrossRef] 
96. Maffeis, V.; Nicolè, L.; Cappellesso, R. RAS, Cellular Plasticity, and Tumor Budding in Colorectal Cancer. Front. Oncol. 2019, 9. [CrossRef]

97. Carethers, J.M.; Jung, B.H. Genetics and Genetic Biomarkers in Sporadic Colorectal Cancer. Gastroenterology 2015, 149, 1177-1190. [CrossRef] [PubMed]

98. Worthley, D.L.; Whitehall, V.L.; Spring, K.J.; Leggett, B.A. Colorectal carcinogenesis: Road maps to cancer. World J. Gastroenterol. 2007, 13, 3784-3791. [CrossRef]

99. Koncina, E.; Haan, S.; Rauh, S.; Letellier, E. Prognostic and Predictive Molecular Biomarkers for Colorectal Cancer: Updates and Challenges. Cancers 2020, 12, 319. [CrossRef]

100. Blons, H.; Emile, J.F.; Le Malicot, K.; Julié, C.; Zaanan, A.; Tabernero, J.; Mini, E.; Folprecht, G.; Van Laethem, J.L.; Thaler, J.; et al. PETACC-8 Study Investigators, Prognostic value of KRAS mutations in stage III colon cancer: Post hoc analysis of the PETACC8 phase III trial dataset. Ann. Oncol. 2014, 25, 2378-2385. [CrossRef] [PubMed]

101. Phipps, A.I.; Buchanan, D.D.; Makar, K.W.; Win, A.K.; Baron, A.J.; Lindor, N.M.; Potter, J.D.; Newcomb, P.A. KRAS-mutation status in relation to colorectal cancer survival: The joint impact of correlated tumour markers. Br. J. Cancer 2013, 108, 1757-1764. [CrossRef]

102. Rajagopalan, H.; Bardelli, A.; Lengauer, C.; Kinzler, K.W.; Vogelstein, B.; Velculescu, V.E. Tumorigenesis: RAF/RAS oncogenes and mismatch-repair status. Nature 2002, 418, 934. [CrossRef]

103. Davies, H.; Bignell, G.R.; Cox, C.; Stephens, P.; Edkins, S.; Clegg, S.; Teague, J.; Woffendin, H.; Garnett, M.J.; Bottomley, W.; et al. Mutations of the BRAF gene in human cancer. Nature 2002, 417, 949-954. [CrossRef] [PubMed]

104. Ikenoue, T.; Kanai, F.; Hikiba, Y.; Obata, T.; Tanaka, Y.; Imamura, J.; Ohta, M.; Jazag, A.; Guleng, B.; Tateishi, K.; et al. Functional analysis of PIK3CA gene mutations in human colorectal cancer. Cancer Res. 2005, 65, 4562-4567. [CrossRef]

105. Salem, M.E.; Weinberg, B.A.; Xiu, J.; El-Deiry, W.S.; Hwang, J.J.; Gatalica, Z.; Philip, P.A.; Shields, A.F.; Lenz, H.-J.; Marshall, J.L. Comparative molecular analyses of left-sided colon, right-sided colon, and rectal cancers. Oncotarget 2017, 8, 86356-86368. [CrossRef] [PubMed]

106. Salem, M.E.; Battaglin, F.; Goldberg, R.M.; Puccini, A.; Shields, A.F.; Arguello, D.; Korn, W.M.; Marshall, J.L.; Grothey, A.; Lenz, H. Molecular Analyses of Left- and Right-Sided Tumors in Adolescents and Young Adults with Colorectal Cancer. Oncologist 2019. [CrossRef] [PubMed]

107. Tol, J.; Punt, C.; Nagtegaal, I. BRAF mutation in metastatic colorectal cancer. N. Engl. J. Med. 2009, 361, 98-99. [CrossRef] [PubMed]

108. Vogelstein, B.; Lane, D.P.; Levine, A.J. Surfing the p53 network. Nature 2000, 408, 307-310. [CrossRef] [PubMed]

109. Vogelstein, B.; Hamilton, S.R.; Preisinger, A.C.; Leppert, M.; Smits, A.M.; Bos, J.L.; Fearon, E.R.; Kern, S.E. Genetic alterations during colorectal-tumor development. N. Engl. J. Med. 1988, 319, 525-532. [CrossRef] [PubMed]

110. Markowitz, S.D.; Bertagnolli, M.M. Molecular origins of cancer: Molecular basis of colorectal cancer. N. Engl. J. Med. 2009, 361, 2449-2460. [CrossRef]

111. Munro, A.; Lain, S.; Lane, D.P. P53 abnormalities and outcomes in colorectal cancer: A systematic review. Br. J. Cancer 2005, 92, 434-444. [CrossRef] [PubMed]

112. Mouradov, D.; Domingo, E.; Gibbs, P.; Jorissen, R.N.; Li, S.; Soo, P.Y.; Lipton, L.; Desai, J.; Danielsen, H.E.; Oukrif, D.; et al. Survival in stage II/III colorectal cancer is independently predicted by chromosomal and microsatellite instability, but not by specific driver mutations. Am. J. Gastroenterol. 2013, 108, 1785-1793. [CrossRef] [PubMed]

113. Warren, R.S.; Atreya, C.E.; Niedzwiecki, N.; Weinberg, V.K.; Donner, D.B.; Mayer, R.J.; Goldberg, R.M.; Compton, C.C.; Zuraek, M.B.; Ye, C.; et al. Association of TP53 Mutational Status and Gender with Survival after Adjuvant Treatment for Stage III Colon Cancer: Results of CALGB 89803. Clin. Cancer Res. 2013. [CrossRef] [PubMed]

114. Donada, M.; Bonin, S.; Barbazza, R.; Pettirosso, D.; Stanta, G. Management of stage II colon cancer-The use of molecular biomarkers for adjuvant therapy decision. BMC Gastroenterol. 2013, 13, 36. [CrossRef] [PubMed] 
115. Jiang, D.; Wang, L.; Zhao, T.; Zhang, Z.; Zhang, R.; Jin, J.; Cai, Y.; Wang, F. Restoration of the tumor-suppressor function to mutant p53 by Ganoderma lucidum polysaccharides in colorectal cancer cells. Oncol. Rep. 2017, 37, 594-600. [CrossRef]

116. Petit, T.; Bearss, D.; Troyer, D.A.; Munoz, R.M.; Windle, J.J. p53-independent response to cisplatin and oxaliplatin in MMTV-ras mouse salivary tumors. Mol. Cancer Ther. 2003, 2, 165-171.

117. Seo, Y.R.; Chen, E.I.-T.; Smith, M.L. Sensitivity of p53-deficient cells to oxaliplatin and thio-TEPA (N, N', N" triethylenethiophosphoramide). Breast Cancer Res. Treat. 2002, 72, 255-263. [CrossRef] [PubMed]

118. Lavin, M.F.; Gueven, N. The complexity of p53 stabilization and activation. Cell Death Differ. 2006, 13, 941-950. [CrossRef] [PubMed]

119. Chang, F.; Lee, J.T.; Navolanic, P.M.; Steelman, L.S.; Shelton, J.G.; Blalock, W.; Franklin, R.A.; McCubrey, J. Involvement of PI3K/Akt pathway in cell cycle progression, apoptosis, and neoplastic transformation: A target for cancer chemotherapy. Leukemia 2003, 17, 590-603. [CrossRef] [PubMed]

120. McCubrey, J.A.; Steelman, L.S.; Chappell, W.H.; Abrams, S.L.; Franklin, R.A.; Montalto, G.; Cervello, M.; Libra, M.; Candido, S.; Malaponte, G.; et al. Ras/Raf/MEK/ERK and PI3K/PTEN/Akt/mTOR cascade inhibitors: How mutations can result in therapy resistance and how to overcome resistance. Oncotarget 2012, 3, 1068-1111. [CrossRef]

121. Jin, J.; Shi, Y.; Zhang, S.; Yang, S. PIK3CA mutation and clinicopathological features of colorectal cancer: A systematic review and Meta-Analysis. Acta Oncol. 2019, 59, 66-74. [CrossRef]

122. Tsilimigras, D.I.; Ntanasis-Stathopoulos, I.; Bagante, F.; Moris, D.; Cloyd, J.M.; Spartalis, E.; Pawlik, T.M. Clinical significance and prognostic relevance of KRAS, BRAF, PI3K and TP53 genetic mutation analysis for resectable and unresectable colorectal liver metastases: A systematic review of the current evidence. Surg. Oncol. 2018, 27, 280-288. [CrossRef]

123. Wang, Q.; Shi, Y.-L.; Zhou, K.; Wang, L.-L.; Yan, Z.-X.; Liu, Y.-L.; Xu, L.-L.; Zhao, S.-W.; Chu, H.-L.; Shi, T.-T.; et al. PIK3CA mutations confer resistance to first-line chemotherapy in colorectal cancer. Cell Death Dis. 2018, 9, 739. [CrossRef] [PubMed]

124. Xu, J.; Wang, Y.-L.; Wang, Y.; Liu, T.; Ni, M.; Li, M.; Lin, L.; Ge, F.-J.; Gong, C.; Gu, J.-Y.; et al. PIK3CA Mutations Contribute to Acquired Cetuximab Resistance in Patients with Metastatic Colorectal Cancer. Clin. Cancer Res. 2017, 23, 4602-4616. [CrossRef]

125. Andre, F.; Ciruelos, E.; Rubovszky, G.; Campone, M.; Loibl, S.; Rugo, H.S.; Iwata, H.; Conte, P.; Mayer, I.A.; Kaufman, B.; et al. Alpelisib for PIK3CA-Mutated, Hormone Receptor-Positive Advanced Breast Cancer. N. Engl. J. Med. 2019, 380, 1929-1940. [CrossRef] [PubMed]

126. Christie, M.; Jorissen, R.N.; Mouradov, D.; Sakthianandeswaren, A.; Li, S.; Day, F.; Tsui, C.; Lipton, L.; Desai, J.; Jones, I.T; et al. Different APC genotypes in proximal and distal sporadic colorectal cancers suggest distinct $\mathrm{WNT} / \beta$-catenin signalling thresholds for tumourigenesis. Oncogene 2013, 32, 4675-4682. [CrossRef]

127. Clevers, H. Wnt/beta-catenin signaling in development and disease. Cell 2006, 127, 469-480. [CrossRef]

128. Venook, A.P.; Niedzwiecki, N.; Lenz, H.-J.; Innocenti, F.; Fruth, B.; Meyerhardt, J.A.; Schrag, D.; Greene, C.; O'Neil, B.H.; Atkins, J.N.; et al. Blanke, Effect of First-Line Chemotherapy Combined With Cetuximab or Bevacizumab on Overall Survival in Patients With KRAS Wild-Type Advanced or Metastatic Colorectal Cancer: A Randomized Clinical Trial. JAMA 2017, 317, 2392-2401. [CrossRef]

129. Rivera, F.; Karthaus, M.; Hecht, J.R.; Sevilla, I.; Forget, F.; Fasola, G.; Canon, J.-L.; Guan, X.; Demonty, G.; Schwartzberg, L.S. Final analysis of the randomised PEAK trial: Overall survival and tumour responses during first-line treatment with mFOLFOX6 plus either panitumumab or bevacizumab in patients with metastatic colorectal carcinoma. Int. J. Colorectal Dis. 2017, 32, 1179-1190. [CrossRef]

130. Heinemann, V.; Von Weikersthal, L.F.; Decker, T.; Kiani, A.; Vehling-Kaiser, U.; Al-Batran, S.-E.; Heintges, T.; Lerchenmüller, C.; Kahl, C.; Seipelt, G.; et al. FOLFIRI plus cetuximab versus FOLFIRI plus bevacizumab as first-line treatment for patients with metastatic colorectal cancer (FIRE-3): A randomised, open-label, phase 3 trial. Lancet Oncol. 2014, 15, 1065-1075. [CrossRef]

131. Le, D.T.; Uram, J.N.; Wang, H.; Bartlett, B.; Kemberling, H.; Eyring, A.D.; Skora, A.D.; Luber, B.S.; Azad, N.S.; Laheru, D.; et al. PD-1 Blockade in Tumors with Mismatch-Repair Deficiency. N. Engl. J. Med. 2015, 372, 2509-2520. [CrossRef] 
132. Eng, C.; Kim, T.W.; Bendell, J.; Argilés, G.; Tebbutt, N.C.; Di Bartolomeo, M.; Falcone, A.; Fakih, M.; Kozloff, M.; Segal, N.H.; et al. IMblaze370 Investigators, Atezolizumab with or without cobimetinib versus regorafenib in previously treated metastatic colorectal cancer (IMblaze370): A multicentre, open-label, phase 3, randomised, controlled trial. Lancet Oncol. 2019, 20, 849-861. [CrossRef]

133. Hermel, D.J.; Sigal, D. The Emerging Role of Checkpoint Inhibition in Microsatellite Stable Colorectal Cancer. J. Pers. Med. 2019, 9, 5. [CrossRef]

134. Chalabi, M.; Fanchi, L.F.; Dijkstra, K.K.; Berg, J.G.V.D.; Aalbers, A.G.; Sikorska, K.; Lopez-Yurda, M.; Grootscholten, C.; Beets, G.; Snaebjornsson, P.; et al. Neoadjuvant immunotherapy leads to pathological responses in MMR-proficient and MMR-deficient early-stage colon cancers. Nat. Med. 2020, 26, 566-576. [CrossRef] [PubMed]

135. Sinicrope, F.A.; Ou, F.-S.; Zemla, T.; Nixon, A.B.; Mody, K.; Levasseur, A.; Dueck, A.C.; Dhanarajan, A.R.; Lieu, C.H.; Cohen, D.J.; et al. Randomized trial of standard chemotherapy alone or combined with atezolizumab as adjuvant therapy for patients with stage III colon cancer and deficient mismatch repair (ATOMIC, Alliance A021502). J. Clin. Oncol. 2019, 37, e15169. [CrossRef]

136. Spranger, S.; Gajewski, T.F. Tumor-intrinsic oncogene pathways mediating immune avoidance. Oncoimmunology 2016, 5, e1086862. [CrossRef] [PubMed]

137. Yang, L.; Li, A.; Lei, Q.; Zhang, Y. Tumor-intrinsic signaling pathways: Key roles in the regulation of the immunosuppressive tumor microenvironment. J. Hematol. Oncol. 2019, 12, 125. [CrossRef] [PubMed]

138. Wang, T.; Niu, G.; Kortylewski, M.; Burdelya, L.; Shain, K.; Zhang, S.; Bhattacharya, R.; Gabrilovich, D.; Heller, R.; Coppola, D.; et al. Regulation of the innate and adaptive immune responses by Stat-3 signaling in tumor cells. Nat. Med. 2003, 10, 48-54. [CrossRef] [PubMed]

139. Ihara, S.; Kida, H.; Arase, H.; Tripathi, L.P.; Chen, Y.-A.; Kimura, T.; Yoshida, M.; Kashiwa, Y.; Hirata, H.; Fukamizu, R.; et al. Inhibitory roles of signal transducer and activator of transcription 3 in antitumor immunity during carcinogen-induced lung tumorigenesis. Cancer Res. 2012, 72, 2990-2999. [CrossRef]

140. Lastwika, K.J.; Wilson, W.; Li, Q.K.; Norris, J.; Xu, H.; Ghazarian, S.R.; Kitagawa, H.; Kawabata, S.; Taube, J.M.; Yao, S.; et al. Control of PD-L1 Expression by Oncogenic Activation of the AKT-mTOR Pathway in Non-Small Cell Lung Cancer. Cancer Res. 2016, 76, 227-238. [CrossRef]

141. Crane, C.A.; Panner, A.; Murray, J.C.; Wilson, S.P.; Xu, H.; Chen, L.; Simko, J.P.; Waldman, F.M.; Pieper, R.O.; Parsa, A.T. PI(3) kinase is associated with a mechanism of immunoresistance in breast and prostate cancer. Oncogene 2009, 28, 306-312. [CrossRef]

142. Coelho, M.A.; Trécesson, S.D.C.; Rana, S.; Zecchin, D.; Moore, C.; Molina-Arcas, M.; East, P.; Spencer-Dene, B.; Nye, E.; Barnouin, K.; et al. Oncogenic RAS Signaling Promotes Tumor Immunoresistance by Stabilizing PD-L1 mRNA. Immunity. 2017, 47, 1083-1099. [CrossRef]

143. Pinter, M.; Jain, R.K. Targeting the renin-angiotensin system to improve cancer treatment: Implications for immunotherapy. Sci. Transl. Med. 2017, 9. [CrossRef] [PubMed] 